\title{
Emission Control Technologies in Spark Ignition Engines
}

\author{
Khaled Abouemara ${ }^{1}$ and Samer Fikry ${ }^{1}$ \\ ${ }^{1}$ Qatar University, Doha, Qatar \\ DOI: doi.org.10.47611/jsr.v9i1.1101
}

\section{$\underline{\text { ABSTRACT }}$}

This paper extensively discusses a review of the latest technologies considered controlling emissions in spark-ignition engines in addition to the background and history of the industry. Moreover, the paper discusses in detail the significant pollutants affecting the environment negatively, which are Carbon Monoxide (CO), Hydrocarbons (HC), Oxides of Nitrogen $\left(\mathrm{NO}_{\mathrm{x}}\right)$, Sulfur Oxides $\left(\mathrm{SO}_{\mathrm{x}}\right)$, Carbon Dioxide $\left(\mathrm{CO}_{2}\right)$, and Particulates. Furthermore, the crankcase emissions, the fuel system, and the exhaust system are discussed, which are considered to be the primary sources of pollution coming from a conventional spark-ignition engine. The major emission control technologies in spark-ignition engines, among numerous methods, could be shortlisted in the following factors: modifications in the engine design and operating parameters, treatment of exhaust products of combustion, and improvement of the fuels. Each technology has its branches and subcategories. In this paper, mainly the most prominent, up to date, and effective technologies were reviewed and discussed, which are lean combustion, design of a muffler, automatic hot air intake system, engine compression ratio, modification of combustion chamber, modification of the fuels, treatment of exhaust products of combustion, three-way, and four-way catalytic converters, exhaust gas recirculation (EGR), total emissions control packages, pre-combustion control; (Positive Crankcase Ventilation (PCV)), and valve gear design. The points covered were related but not limited to the three main categories mentioned above. Finally, a conclusion and recommendations for future work are considered.

\section{Introduction}

Vehicles or automobiles are considered to be the primary transportation method for humankind for more than a century. These automobiles can utilize the source of mechanical energy obtained from the internal combustion engine, where the internal combustion engine converts chemical energy into mechanical energy. During the energy conversion process, the fuel oxidation in the form of combustion is present. Burning fossil fuels have been linked with its emissions in the form of nitrogen oxides (NOX), sulfur oxides (SOX), carbon monoxide (CO), and unburned hydrocarbons (UBHC). The previously mentioned emissions have both local and global impacts. Hence, it can be claimed that automobiles have a negative influence when it comes to the environmental aspect or context as emissions from automobiles lead to global warming, which is a severe threat and danger to the whole world. By the time, large and metropolitan cities have witnessed and experienced a considerable increase in automobiles' usage leading to the rising of 
a significant concern, which is environmental protection issues. As a result, all countries and territories have introduced emission control regulations intending to reduce vehicles' emissions powered by internal combustion engines, where researchers and experts have prioritized and shed light on engine designs in addition to exhaust emission control from internal combustion engines. Globally, gasoline spark-ignition engines are the most known and famous for passenger vehicles. Eventually, there were control methods and techniques developed to reduce exhaust emissions from spark-ignition engines. It has been clear and evident that the control of exhaust gas emissions from conventional gasoline engines has been improved and enhanced over the last three decades, introducing catalysts. Petrol or gasoline engines are broadly and extensively used for numerous applications in automobiles. The spark-ignition engine is a favored prime mover because of its smooth working and low maintains.

Moreover, it is characterized by low specific weight, compactness, and simplicity in design. On the other hand, the spark-ignition engine has two sincere disadvantages and defects, which are low fuel economy and high-unburned hydrocarbon emissions. Since 1980 the automotive emissions' issue has been strictly regulated. Therefore, a lot of novel technologies and innovations has been brought to the table, most notable at that time was the three-way catalyst (TWC), which has been used to convert toxic emissions released from spark-ignition engines such as; hydrocarbons, carbon monoxide, and oxides of nitrogen into less toxic gases in a trial of meeting and fitting the authorized strict regulations and guidelines.

\section{Literature Review}

First, a tour in the history of the issue began during the 1950s when the vehicles were claimed and stated to be the primary source of air pollution in the United States cities. Firstly, carbon monoxide, unburned fuel (hydrocarbons), nitrogen oxides, and smoke particulates were categorized as the main air pollutants, and then nowadays, carbon dioxide has also been added to the list of toxic and destructive gas emissions due to its well-known global warming effect. Confronting such an issue was necessary. Firstly, to overcome the air pollution conflict, during the 1960s, attempts were mainly concentrated on the reduction of $\mathrm{CO}$ from gasoline vehicles in addition to black smoke emissions from diesel vehicles. Furthermore, preventing blue smoke emissions produced by powerful engine lubricating oils resulted from overused piston rings, cylinder bore, etc. The first emission control technology or method for the spark ignition engines included alterations and air-fuel ratio adjustments. Proceeding by, it was followed by other method and techniques, mainly controlling and adjusting other engine factors such as; mixture control under idling, acceleration, and deceleration, spark timing, accurate and precise manufacturing of main engine parts such as pistons, rings, cylinder head gasket to minimize crevice volume, cams, valves, etc. During the mid of 1960s, another technique was introduced on gasoline automobiles: the positive crankcase ventilation (PCV) to block releasing hydrocarbon-rich crankcase blow-by gases into the atmosphere and surroundings. That period was followed by tightening the standards and guidelines of emissions' issue. Therefore, a critical technology was innovated and commercialized for the first time in 19741975, the catalytic converter, which is considered an exhaust after-treatment apparatus or device. Also, more progressive and advanced fuel systems and engine design modifications and adjustments took place. As the concern and issue develop over time, managing engines and electronic fuel became essential during the 1980s to cope with the standards and regulations. 
Moreover, additional improvements and progress took place in engines and fuel systems and rising emission control methods and technologies at that time. During the late 1980s, multi-valve cylinder engines turned into typical and frequent ones in addition to applying variable valve actuation to production automobiles and vehicles. Gasoline and applied charge (DISC) engines were innovated and produced by the Japanese manufacturers in such a field during the mid-1990s. Despite developing such control technologies in engines' production and exhaust after-treatment systems through time, alternative power trains have been introduced and developed in the past decade, providing and contributing to higher fuel efficiency accompanied by very low emissions. Nowadays, there are hybrid electric vehicles (HEV) available in the automobiles and vehicles marketplace. IC engines characterize these vehicles as an essential fundamental source of power. However, they utilize electric propulsion operated and powered by storage batteries as the central propulsion unit. Fuel cell vehicles and automobiles adopt using hydrogen as the primary energy source. These vehicles are ahead in position and in a leading stage of development, where they eliminate the use of IC engines as a propulsion drive system.

\section{Pollutants}

The word "smog" is invented and created many years ago form "smoke" and "fog."

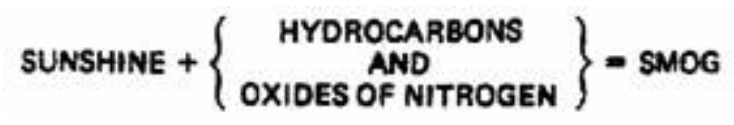

Figure 1: Smog formation.

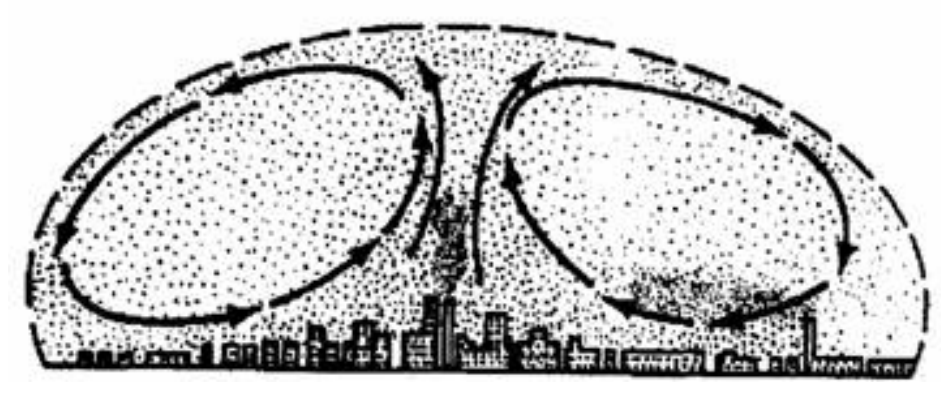

Figure 2: The heat generated within a large city tends to produce a circulatory air pattern which traps smog within a dome.

To define air pollution, it can be claimed to be an addition to the air or atmosphere of any material, which will have a negative impact, effect, or influence on life upon planet earth. Not only engines that cause air pollution, electric power stations, and industrial and domestic fuel consumers also stimulate and contribute to pollution. It is a conventional practice to express the quantity of a gas pollutant present in the air as parts per million (ppm). Therefore, 


$$
\begin{aligned}
& 1 \mathrm{ppm}=\frac{1 \text { volume of gaseous pollutant }}{10^{6} \text { volumes (polutant }+ \text { air) }} \\
& 1 \mathrm{ppm}=0.0001 \text { percent by volume }
\end{aligned}
$$

The mass of a pollutant is expressed as micrograms of pollutants per cubic meter of air $(\mu \mathrm{g} / \mathrm{m} 3)$.

$$
\mu g / \mathrm{m}^{3}=\frac{\text { ppm } \times \text { molecular weight }}{24.5}\left(10^{3}\right)
$$

The fundamental relation between $\mu \mathrm{g} / \mathrm{m} 3$ and ppm at $1 \mathrm{~atm}$ and $25^{\circ} \mathrm{C}$ is

For vehicle and automobile engines, the pollutant is measured in grams per kilowatt per hour (g/kWh). The emission limits are measured by grams per kilometer travel $(\mathrm{g} / \mathrm{km})$ or $(\mathrm{g} / \mathrm{mile})$. The carbon dioxide $\left(\mathrm{CO}_{2}\right)$, water vapor, Oxygen $\left(\mathrm{O}_{2}\right)$, and Nitrogen $\left(\mathrm{N}_{2}\right)$ are sometimes measured as a volume percentage (Vol\%). Pollutants contributing to air pollution are created and produced by the incomplete burning of the combustion chamber's air-fuel mixture. The major pollutants emitted from the exhaust due to such a process are:

- $\quad$ Carbon monoxide (CO).

- Hydrocarbons (HC).

- $\quad$ Oxides of nitrogen (NO).

Other products emitted are particulates, sulfur oxides, acetylene, aldehydes, etc. In case a complete combustion process occurs, the only products that will be discharged and emitted from the exhaust would be nontoxic water vapor and carbon dioxide, which is not directly harmful to humans.

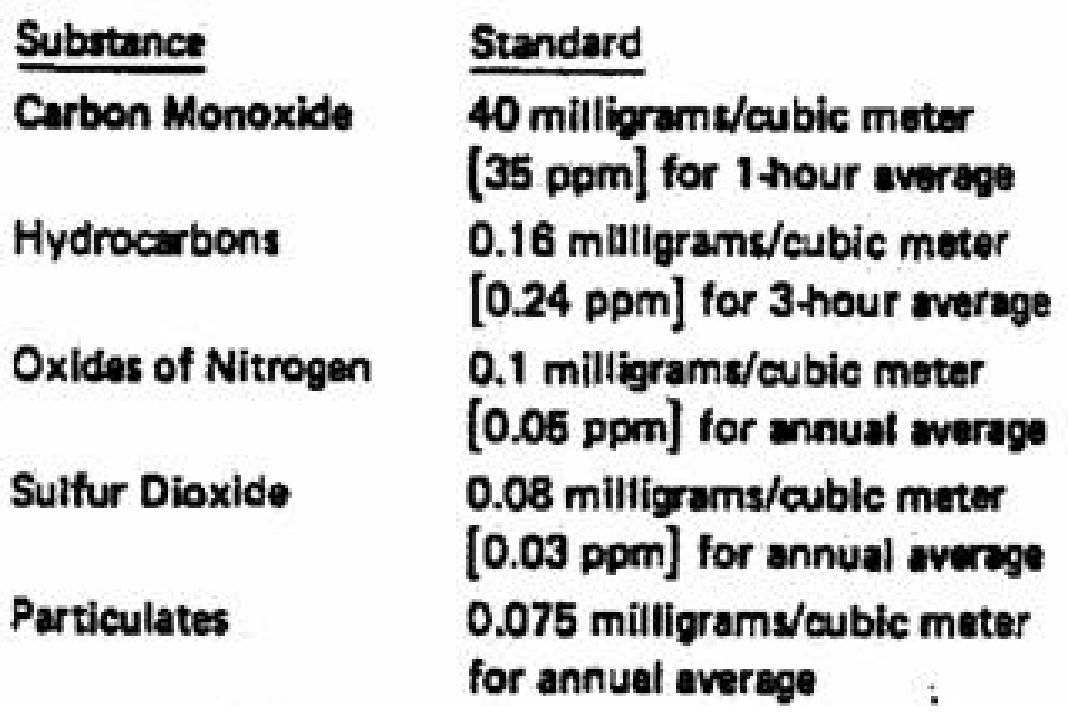

Figure 3: Ambient air quality standards for each pollutant. (Society of Automotive Engineers, Inc.). 


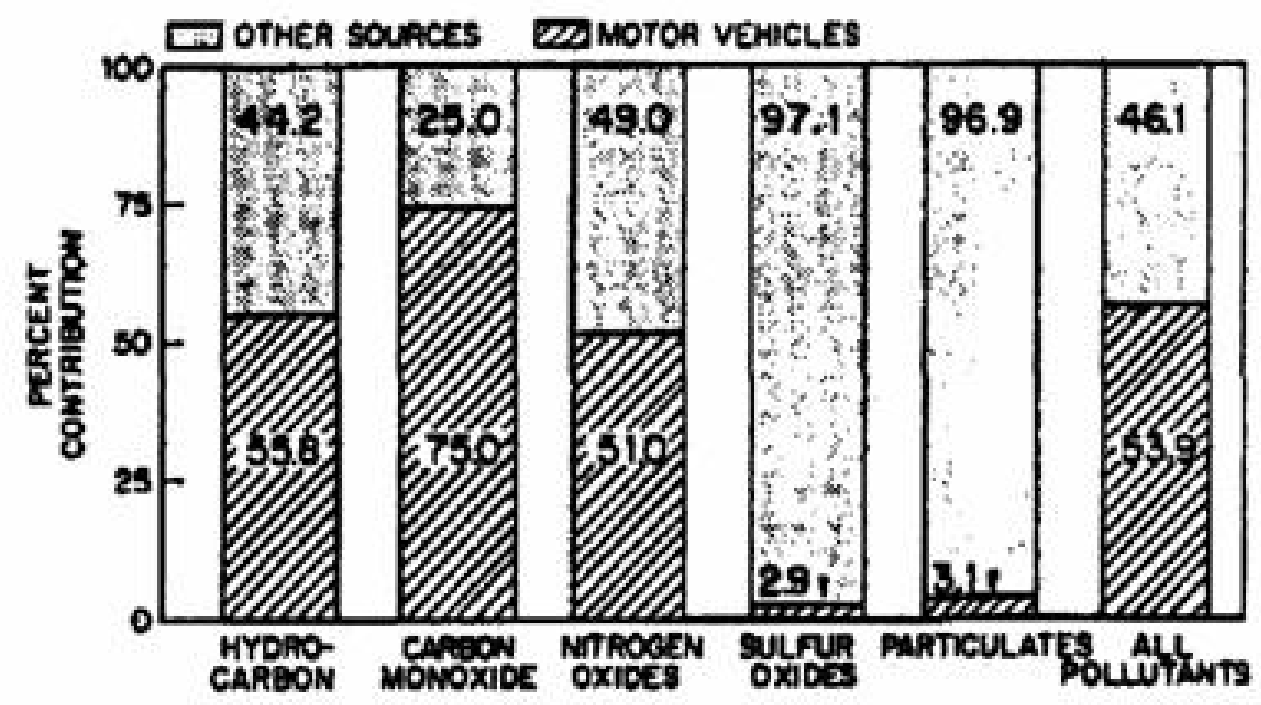

Figure 4: Percentage of air pollution caused by motor vehicles and by other sources. (Society of Automotive Engineers, Inc.).

\begin{tabular}{|c|c|c|c|c|c|c|}
\hline POLLLTANT & $\begin{array}{l}\text { TRWNSPPOR- } \\
\text { TATION }\end{array}$ & $\begin{array}{l}\text { FUE, COM- } \\
\text { BUSTION, } \\
\text { STATHONARY } \\
\text { SOURCES }\end{array}$ & $\begin{array}{l}\text { INDUSTRLLL } \\
\text { PROCESSES }\end{array}$ & $\begin{array}{c}\text { SOLID } \\
\text { WASTE } \\
\text { Dtsposal }\end{array}$ & $\begin{array}{l}\text { Mascel } \\
\text { LANBous }\end{array}$ & TOTAL. \\
\hline $\begin{array}{l}\mathrm{CO} \\
\mathrm{SO}_{x} \\
\mathrm{NO}_{x} \\
\mathrm{C}_{z} \mathrm{H}_{y} \\
\text { Rarticulate } \\
\text { TOTNL. } \\
\text { Prackert }\end{array}$ & $\begin{array}{r}85.7 \\
0.8 \\
9.2 \\
11.5 \\
1.1 \\
108.3 \\
55.9\end{array}$ & $\begin{array}{r}1.2 \\
22.4 \\
13.0 \\
1.5 \\
4.8 \\
42.9 \\
22.1\end{array}$ & $\begin{array}{r}8.3 \\
4.2 \\
0.7 \\
10.1 \\
5.4 \\
28.7 \\
14.8\end{array}$ & $\begin{array}{l}2.6 \\
0 . \\
0.1 \\
0.7 \\
0.4 \\
3.8 \\
2.0\end{array}$ & \begin{tabular}{l|}
4.9 \\
0. \\
0.1 \\
4.5 \\
0.7 \\
10.2 \\
5.2
\end{tabular} & $\begin{array}{r}102.7 \\
27.4 \\
23.1 \\
28.3 \\
12.4 \\
193.9\end{array}$ \\
\hline
\end{tabular}

NOrr: A zero indicates emisdions of less than 50,000 metric tons per your.

Figure 5: Estimated nationwide emissions for 1977 (108 metric tons/year). 


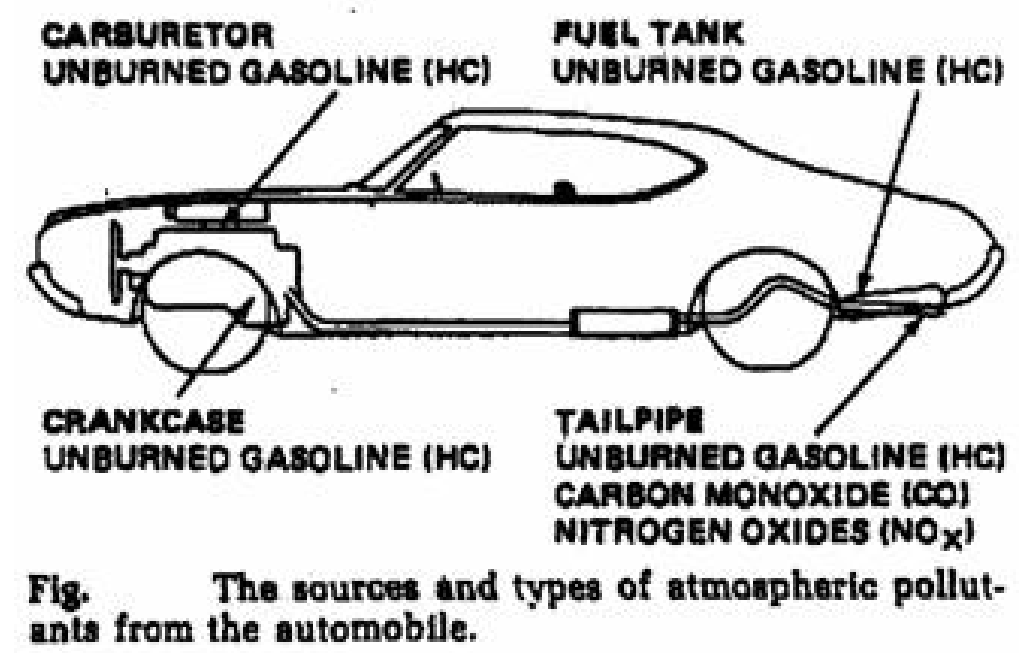

Figure 6: The sources and types of atmospheric pollutants from an automobile.

Excessive $\mathrm{HC}$ and $\mathrm{CO}$ emissions causes:

- Plugged PCV system.

- Excessive rich air/fuel ratio.

- Stuck open heat riser valve.

- Air pumps inoperative or disconnected.

- Engine oil diluted with gasoline.

Lower-than-normal $\mathrm{O} 2$ readings causes:

- Rich air/fuel mixtures.

- Dirty air filter.

- Faulty injectors.

- Higher-than-normal fuel pressures.

- Defective system input sensor.

- Restricted PCV system.

- Charcoal canister purging at idle and low speeds.

Higher-than-normal $\mathrm{O}_{2}$ readings causes:

- Engine misfiring.

- Lean A/F mixtures.

- Vacuum leakages.

- Low fuel pressure.

- Damaged fuel injectors.

- Faulty system input sensor. 


\begin{tabular}{|c|l|c|c|c|c|}
\hline \multicolumn{2}{|c|}{ Numbers in g/mi } & Gasoline & Natural Gas & Methanol & Electricity \\
\hline \multirow{3}{*}{ NMHC } & Vehicle & 0.36 & 0.20 & 0.19 & Neg \\
& Other & 0.18 & 0.06 & 0.06 & 0.03 \\
\cline { 2 - 6 } & Total & 0.54 & 0.26 & 0.25 & 0.03 \\
\hline \multirow{3}{*}{ CO } & Vehicle & 8.25 & 0.03 & 2.90 & Neg \\
& Other & 0.10 & Neg & Neg & 0.10 \\
\cline { 2 - 6 } & Total & 8.35 & 0.03 & 2.90 & 0.10 \\
\hline \multirow{3}{*}{ NO } & Vehicle & 1.50 & 1.15 & 0.47 & Neg \\
& Other & 0.42 & 0.08 & 0.08 & 2.28 \\
\cline { 2 - 6 } & Total & 1.92 & 1.23 & 0.55 & 2.28 \\
\hline \multirow{3}{*}{ SO $\times$ } & Vehicle & 0.12 & Neg & Neg & Neg \\
\cline { 2 - 6 } & Other & 0.59 & Neg & Neg & 1.58 \\
\hline \multirow{3}{*}{ TSP } & Total & 0.71 & Neg & Neg & 1.58 \\
\cline { 2 - 6 } & Other & 0.03 & Neg & Neg & 0.04 \\
\cline { 2 - 6 } & Total & 0.08 & Neg & Neg & 0.04 \\
\hline
\end{tabular}

Figure 7: Estimated emissions from alternatively fueled vehicles.

\section{Carbon Monoxide (CO)}

It is a colorless, odorless, toxic, and poisonous gas characterized by having approximately the same density as air. It appears mostly in the rich mixture as there is not enough oxygen needed for the oxidation of carbon to harmless carbon dioxide. According to the area of fuel excess and extras, the content by volume of $\mathrm{CO}$ increases with decreasing the value of lambda $(\lambda)$ linearly, and according to the area of air excess and extras, the content by volume of CO is low and is independent of the lambda $\lambda$ value. When taking the area of the stoichiometric composition of the mixture into consideration, the content of $\mathrm{CO}$ is approximately 0.3 to $0.5 \%$. It has been claimed that $\mathrm{CO}$ may be chemically active in smog composition. $\mathrm{CO}$, when inhaled, takes the place of the oxygen in the bloodstream where the metabolism of the body will not perform and behave appropriately. Little amounts of $\mathrm{CO}$ concentrations, when inhaled, lessen physical and mental activity and generates headaches. On the other hand, it has been known to kill within 30 minutes when an exposure to a high concentration (> $750 \mathrm{ppm}$ ) occurs directly. The CO content of the exhaust gas from sparkignition engines is exceptionally high at idle. 


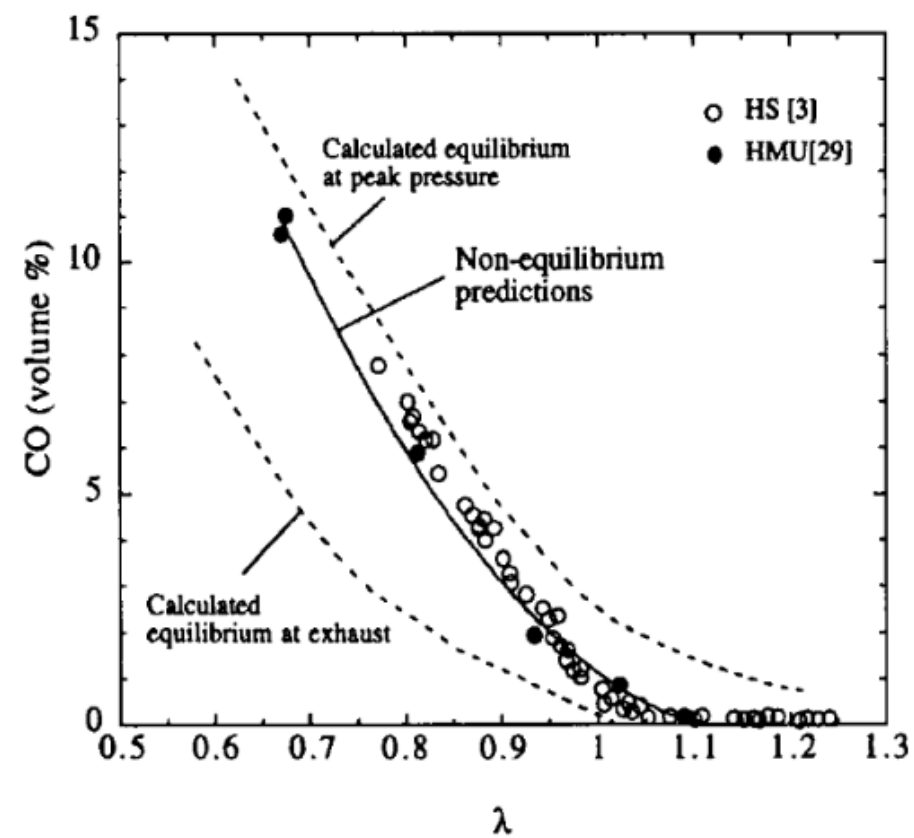

Figure 8: Measurements and predictions of $\mathrm{CO}$ concentrations under steady conditions as a function $\lambda$. Open symbols represent 11 fuels of different composition and volatility.

Mechanism of Formation of Carbon Monoxide (CO): $\mathrm{CO}$ is a transitional product of incomplete combustion if the oxidation of $\mathrm{CO}$ to $\mathrm{CO} 2$ is not complete. It can be stated on a theoretical basis and claimed that a gasoline engine's exhaust is free of $\mathrm{CO}$ if the air-fuel ratio is 15 . However, that is not the real practical case as some $\mathrm{CO}$ is always present in the exhaust even at the lean mixture and can reach $1 \%$. CO is formed when the mixture is rich in fuel. In addition to that, the amount of $\mathrm{CO}$ formed increases as the mixture becomes richer in fuel; this is because equilibrium is not settled and accomplished when the products go to the exhaust. During the high temperature developed during the combustion process, the products formed are unstable. The following reactions take place before the equilibrium is achieved

$$
\begin{aligned}
& 2 \mathrm{H}_{2} \mathrm{O}+\mathrm{O}_{2} \longrightarrow 2(1-\mathrm{y}) \mathrm{H}_{2} \mathrm{O}+2 \mathrm{y} \mathrm{H}_{2}+\mathrm{yO}_{2} \\
& \mathrm{y} \text { is the fraction of } \mathrm{H}_{2} \mathrm{O} \text { detached and separated. } \\
& \mathrm{C}+\mathrm{O}_{2} \longrightarrow \mathrm{CO}_{2} \longrightarrow(1-\mathrm{x}) \mathrm{CO}_{2}+\mathrm{x} \mathrm{CO}+\mathrm{x} / 2 \mathrm{O}_{2}
\end{aligned}
$$

When the products cool down to the exhaust temperature, a prominent and significant part of $\mathrm{CO}$ reacts with oxygen forming $\mathrm{CO}_{2}$. However, a small amount of $\mathrm{CO}$ will remain in the exhaust. 


\section{Excessive carbon monoxide emissions causes:}

- Rich A/F mixtures.

- Contaminated air filter.

- Defective and faulty injectors.

- High fuel pressure.

- Damaged system input sensor.

\section{Hydrocarbons (HC)}

Incomplete combustion leads to unburnt hydrocarbons emissions. The hydrocarbon's emission amount is closely linked with design variables, combustion chamber design, and operating variables such as air-fuel ratio, speed, load, and mode operation as idling, running, or accelerating. Moreover, the surface to volume ratio and wall quenching immensely alter and influence the formation of hydrocarbons. Hydrocarbons are released and emitted by exhausts, engine crankcase fumes, and vapor slipping or breaking away from the carburetor. According to the area of the rich mixture, hydrocarbons' value increases when the $\lambda$ value decreases. $\lambda$ 's minimum value is in the range of 1.1 to 1.2. When compared, hydrocarbons content by volume is massively lower than carbon monoxide content. Its value is expressed in ppm (parts per million) units, and the following apply $1 \%$ of hydrocarbon content by volume $=10000$ ppm. On human health basis, it has been discovered that exposure to hydrocarbons causes some cancers and tumors. Oxides of nitrogen accompanied by unburned hydrocarbons in sunlight form photochemical oxidants, which have undesirable adverse effects on human health and plants.

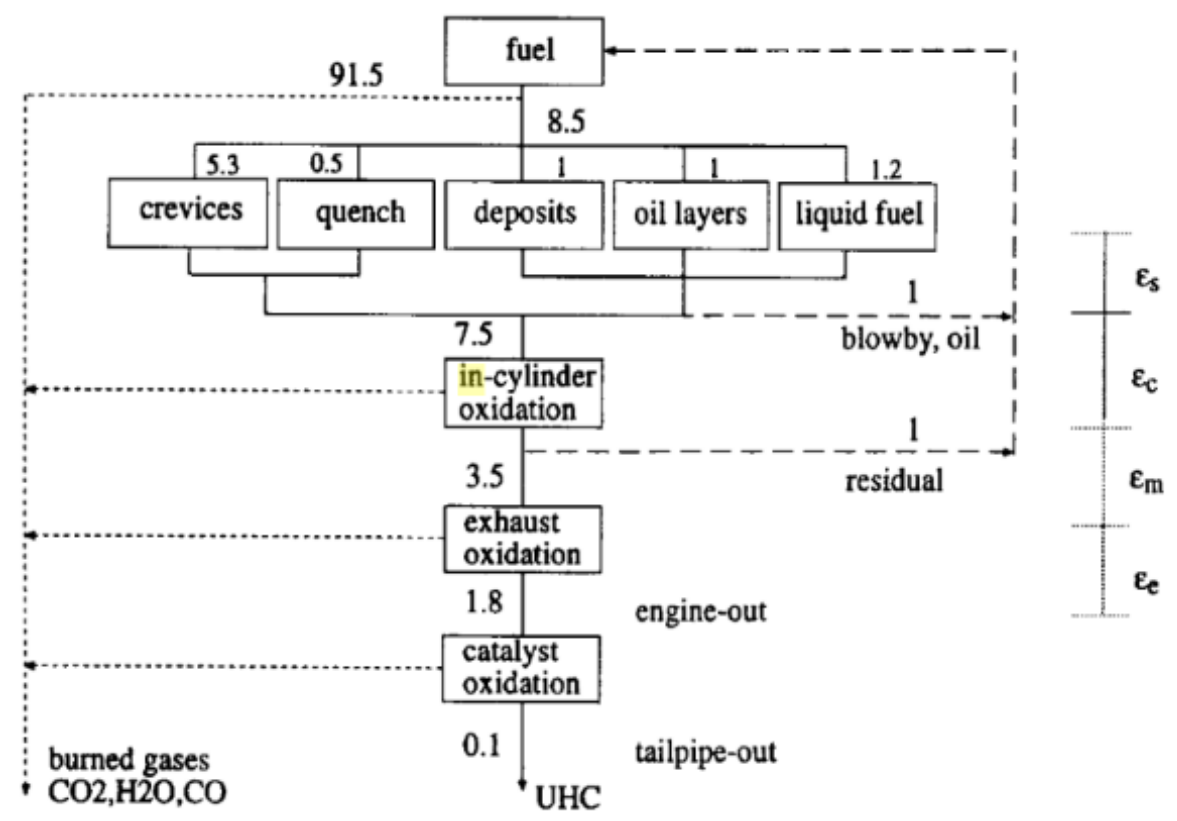

Figure 9: Schematic pathways to formation of HC in SI engines: estimated magnitudes of contributions of HC emission sources during mid-speed and mid-load conditions. 


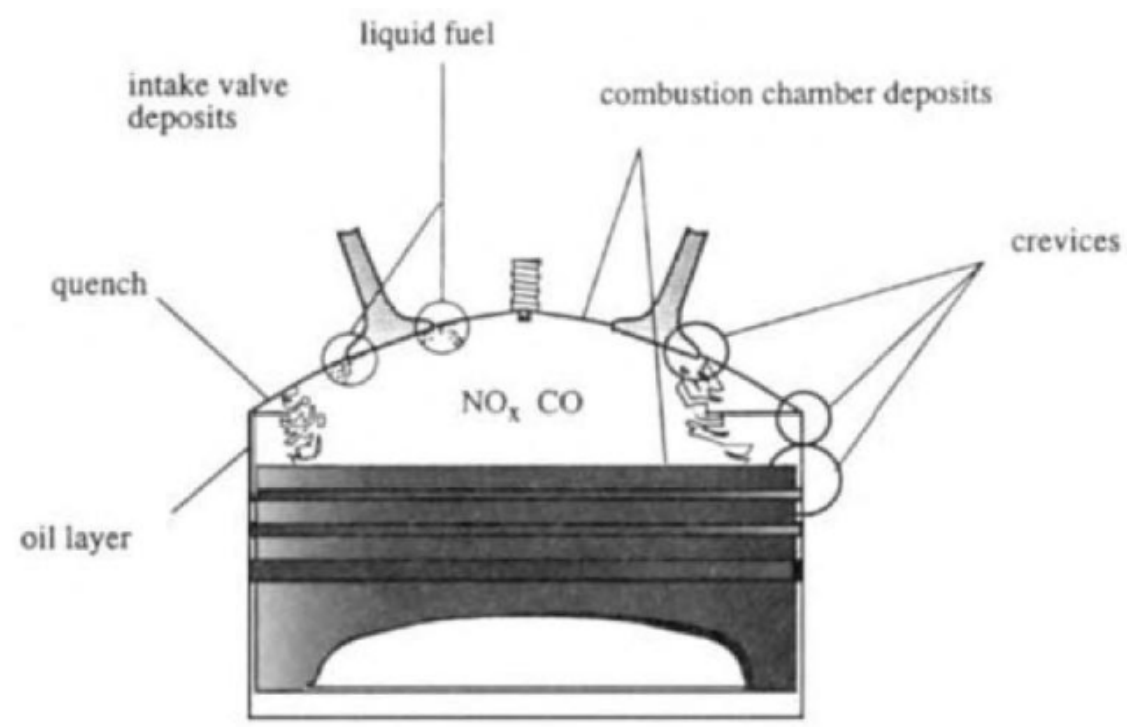

Figure 10: Main sources of $\mathrm{HC}$ emissions.

Mechanism of Formation of Hydrocarbons (HC): The existence of local rich mixture pockets at lower temperatures than the combustion chambers' temperature leads to unburnt hydrocarbons' appearance and existence in the exhaust emitted. Furthermore, hydrocarbons also exist as a result of flame quenching near the metallic walls. However, if the oxygen concentration and exhaust temperature are reasonable and applicable for complete oxidation, a massive quantity and portion of this unburnt hydrocarbon may burn during the expansion and exhaust strokes. Otherwise, a significant amount of hydrocarbon will be emitted with the exhaust gases.

\section{Excessive hydrocarbon emissions causes:}

- Misfiring in the ignition system.

- Improper ignition timing.

- Excessively lean or rich A/F ratio.

- Compression of the cylinder is low.

- Damaged valves, guides, or lifters.

- Damaged rings, pistons, or cylinders.

- Vacuum leakage.

\section{Oxides of Nitrogen $\left(\mathrm{NO}_{x}\right)$}

Oxides of nitrogen exist mainly in the form of $\mathrm{NO}$ and $\mathrm{NO}_{2}$, formed at high temperatures. Therefore, the presence of high temperature and the availability of $\mathrm{O}_{2}$ is the main reason for the formation of nitrogen oxides. $\mathrm{Pure} \mathrm{NO}_{2}$ is a toxic, reddish-brown gas with a harsh odor or smell. $\mathrm{NO}_{2}$ can react with the moisture existing in the air to form nitric acid, damaging materials directly. Many other oxides like $\mathrm{N}_{2} \mathrm{O}_{4}, \mathrm{~N}_{2} \mathrm{O}, \mathrm{N}_{2} \mathrm{O}_{3}, \mathrm{~N}_{2} \mathrm{O}_{5}$ are also formed in low concentration, but they break down immediately at ambient conditions of $\mathrm{NO}_{2}$. The maximum levels of nitrogen oxide are noticed and recognized with air-fuel ratios of approximately $10 \%$ above stoichiometric. When compared, nitrogen oxides' 
dependence on the value of $\lambda$ is typically opposite to carbon monoxide and hydrocarbons. According to the area of fuel excess and extras, oxides of nitrogen increase by increasing the value of $\lambda$ due to increased oxygen concentration. According to the area of a lean mixture, oxides of nitrogen decrease by increasing the value of $\lambda$. Oxides of nitrogen and other destructive, harmful substances are produced in small portions and can cause air pollution in specific environments. Also, prolonged exposure is health threatening. Oxides of nitrogen are also accountable for smog formation (photochemical oxidants), which are the most detrimental to human health.

Mechanism of Formation of Nitric Oxide (NO): At high combustion temperatures, the following chemical reactions take place:

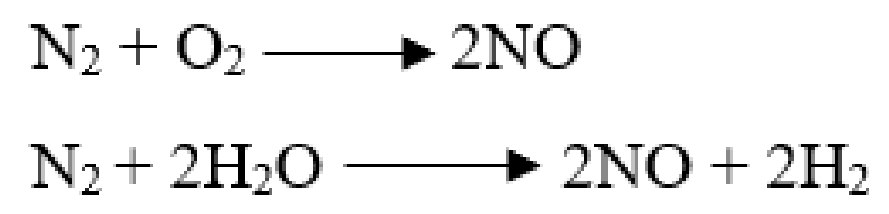

The chemical equilibrium calculations prove that a large amount of NO will be formed at the end of the combustion process. Most of the NO formed will break down at the exhaust's low temperature. However, a portion of NO formed will remain in the exhaust due to the exhaust temperature's low reaction rate. Formation of NO freezes at low exhaust temperatures. Hence, it is far more than the equilibrium composition at that temperature. The NO formation will be less in rich mixtures than in lean ones.

\section{Sulfur Oxides $\left(\mathrm{SO}_{x}\right)$}

Sulfur oxides generally stimulate corrosion of metals. There are numerous negative impacts and influences of acid rain, such as natural water source acidification, which will have a disastrous effect on marine life and demineralization, which by default will lead to a loss in fertility and yield of crops and forests. Many animal species and humankind are affected negatively due to sulfur dioxide, which can cause bronchitis. 


\begin{tabular}{|c|c|}
\hline CONCENTRATION & ETrect \\
\hline $\begin{array}{l}0.03 \mathrm{ppm} \text {, annual average } \\
0.037-0.092 \mathrm{ppm} \text {, annual mean }\end{array}$ & $\begin{array}{l}1974 \text { air quality standard, chronic plant injury } \\
\text { Accompanied by smoke at a concentration of } \\
185 \mu \mathrm{g} / \mathrm{m}^{3} \text {, increased frequency of respiratory } \\
\text { symptoms and lung disease may oocur }\end{array}$ \\
\hline 0.11-0.19 ppm, 24-hr mean & $\begin{array}{l}\text { With low particulate level, increased bospital } \\
\text { admission of older persons for respirationy } \\
\text { diseases may occur. Increased metal } \\
\text { corrosion rate }\end{array}$ \\
\hline $0.19 \mathrm{ppm}, 24-\mathrm{hr}$ mean & $\begin{array}{l}\text { With low particulate level, increased mortality } \\
\text { may occur }\end{array}$ \\
\hline $0.25 \mathrm{ppm}, 24-\mathrm{hr}$ mean & $\begin{array}{l}\text { Accompanied by smoke at a concentration of } \\
750 \mu \mathrm{g} / \mathrm{m}^{3} \text {, increased daily death rate may } \\
\text { occur (British data); a sharp rise in fllness rates }\end{array}$ \\
\hline $\begin{array}{l}0.3 \mathrm{ppm}, 8 \mathrm{hr} \\
0.58 \mathrm{ppm}, 24-\mathrm{hr} \text { average }\end{array}$ & $\begin{array}{l}\text { Some trees show injury } \\
\text { Accompaniod by particulate, Increased mortality } \\
\text { may occur }\end{array}$ \\
\hline
\end{tabular}

sotscr: Summerized from data presented in National Air Pollution Control Administrntion, Atr Quality Citteria for Sulfiur Onides, AP-50. Washington, D.C.: HEW, 1970.

Figure 11: Effects of $\mathrm{SO}_{2}$ at various concentrations.

\section{Carbon Dioxide $\left(\mathrm{CO}_{2}\right)$}

The increase in carbon dioxide's content and concentration in the air will increase the earth's surface temperature. As a result, enough ice will melt, leading to an increase in the oceans' level. This phenomenon is known as the "Greenhouse effect." However, carbon dioxide is a harmless product of the combustion process. The most significant carbon dioxide values are achieved and shown in the stoichiometric ratio area as roughly 14.7 of content $\%$. $\mathrm{CO}_{2}$ value is characterized by having high informative and descriptive values of the engine and its parts' conditions. Whereas, low values of $\mathrm{CO}_{2}$ in addition to low values of $\mathrm{CO}$ and $\mathrm{HC}$ indicate that the exhaust system is leaking. When considering the catalyst convenient and appropriate functioning, the $\mathrm{CO}_{2}$ value can be even greater than when complete combustion occurs.

Lower-than-normal $\mathrm{CO}_{2}$ readings causes:

- Leakage in the exhaust system.

- Rich A/F mixture.

\section{Particulates}

Dehydrogenation, polymerization, and agglomeration commonly and frequently form solid particles. Acetylene $\left(\mathrm{C}_{2} \mathrm{H}_{2}\right)$ is formed as an intermediate product during the combustion process of distinct hydrocarbons. After concurrent polymerization and dehydration, these acetylene molecules produce and yield carbon particles, which are the main elements of the particulate. These particulates exist in the exhaust gases as solids (ash and carbon) or exist in a liquid state. 


\section{Sources of Pollutants from SI Engines}

Below are the three primary sources where pollutants are released and emitted from the SI engine:

- The crankcase: Where piston blow-by fumes and oil mist are emitted to the air and surroundings.

- The fuel system: Where evaporative emissions from the carburetor or gasoline injection air intake and fuel tank are emitted to the air and surroundings.

- The exhaust system: The incomplete combustion process products are emitted and released from the tailpipe to the air and surroundings.

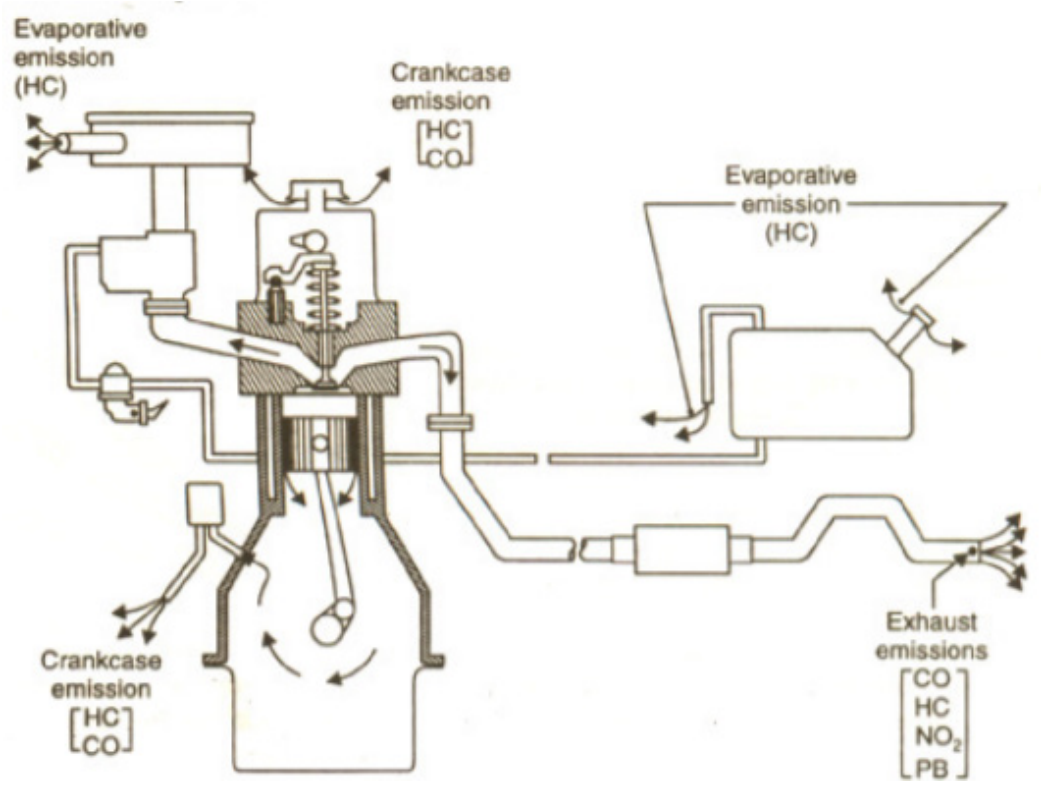

Figure 12: Spark Ignition engine emissions.

\section{The Crankcase Emissions}

The piston and its rings are designed to form a gas-tight enclose and seal between the cylinder walls and the sliding piston. Meanwhile, the real case shows that there will always be compressed charges and burnt fumes breaking away and escaping during the compression and the power stroke to the crankcase. Most of the time, such gases are unburnt air-fuel mixture hydrocarbons, burnt, or partially burnt products of the combustion process; $\mathrm{CO}, \mathrm{CO}_{2}$, or $\mathrm{H}_{2} \mathrm{O}$ (steam). Unfortunately, these products pollute the lubricating oils as well. 
(a) Blow-by during the compression stroke

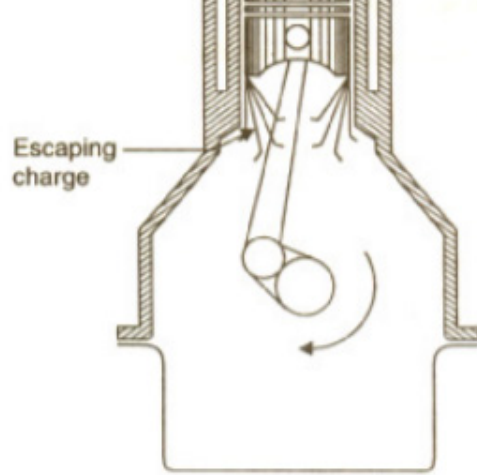

(b) Blow-by during

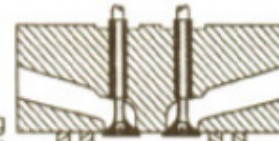

the power stroke

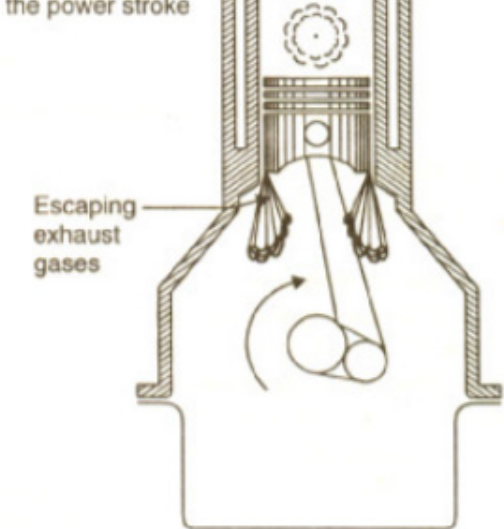

Figure 13: Crankcase emission.

\section{The Fuel System}

Evaporative Emissions: Evaporative emissions lead to emitting roughly 15 to $25 \%$ of total hydrocarbon emissions released from a gasoline engine. Below are the two significant sources of evaporative emissions:

- The fuel tanks.

- The carburetor.

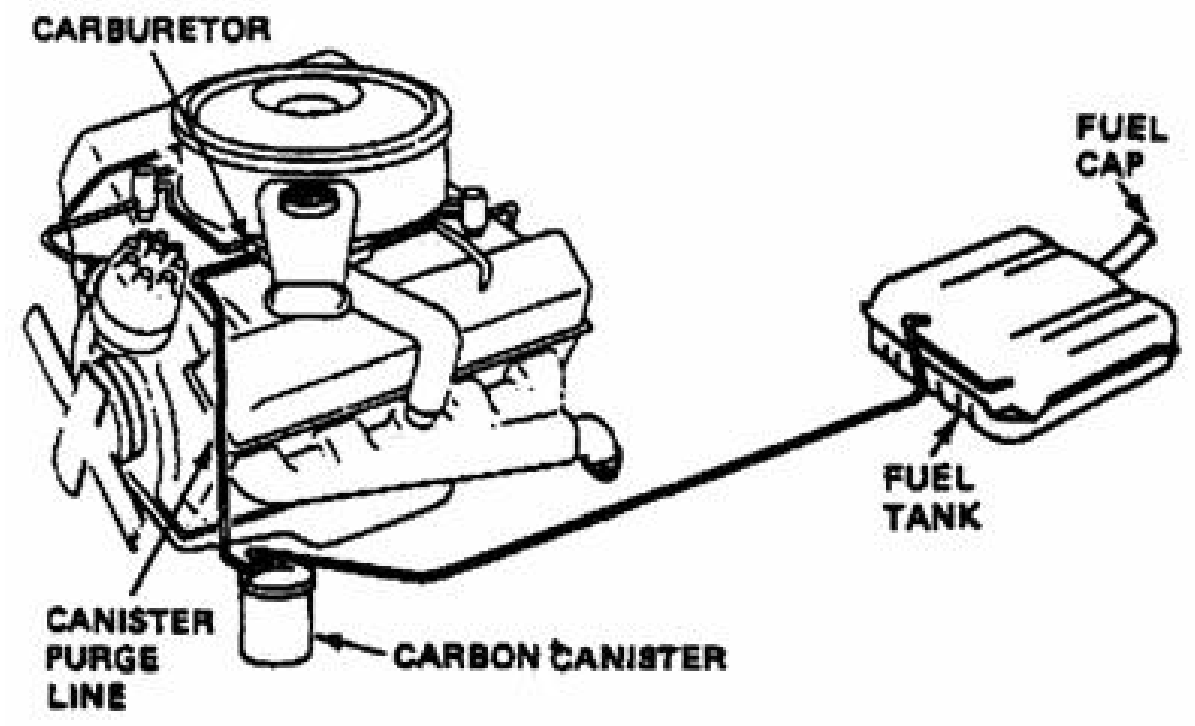

Figure 14: Evaporative control system showing fuel-vapor recovery from the carburetor and fuel tank. (Buick Motor Division of General Motors Corporation). 
Fuel tank losses: The significant aspects and elements ruling the tank emissions are fuel volatility in addition to the ambient temperature. However, the tank's design and location can also affect the emissions, whereas location influences the temperature as well. To reduce fuel tank emissions, Insulation of the tank and the vapor collection systems have been introduced.

Carburetor losses: Even though most internally vented carburetors are equipped with an outside vent that opens at the idle throttle position, the present pressure forces block the vapors' outflow to air and surroundings. Inside vented carburetor may enhance and improve the mixture, leading to increasing the exhaust emissions by default.

\section{The Exhaust System}

The distinct elements emitted and exhausted from a spark-ignition engine are carbon monoxide, unburned hydrocarbons, oxides of nitrogen, and others, which were discussed in the previous section in addition to lead emissions, which are only released and emitted from a spark-ignition engine. Lead is present in the fuel, acting as an antiknock agent in spark-ignition engines. It is impossible to remove and exclude lead completely from all gasoline engines instantly right away as many existing engines rely upon the lubrication supplied by a lead film to avert and avoid fast wear and damage of exhaust valve seats.

\section{Emission Control Technologies in SI Engines}

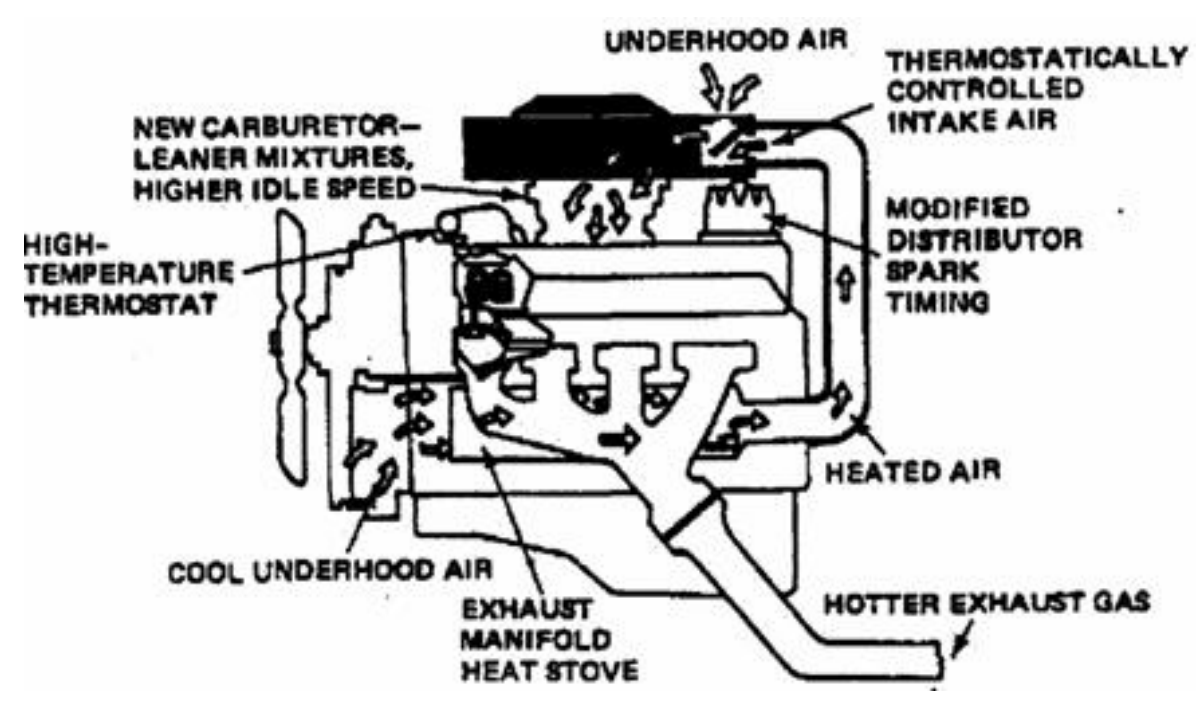

Figure 15: Engine modifications or controlled combustion system (CCS) of exhaust emission control. It is a combination of several engine modifications and calibrations. (Motor Vehicle Manufacturers Association).

\section{Design of a Muffler}

Mufflers are considered to be an essential and crucial element of an engine system. They are conventionally used in exhaust systems to reduce sound transmissions generated by exhaust gases. Designing a muffler is a complicated issue, where it influences noise properties and features, emissions, and fuel efficiency of an engine. As a result, the muffler's 
design becomes more critical for noise minimization. Commonly, a muffler design process is an iterative one by using trial and error. However, in recent years, development in such a field of study occurred were theories and science has provided a way for engineers to cut short the number of iterations.

In conclusion, mufflers minimize noise and exhaust pressure of gases emitted to air and surroundings. A muffler's performance has three aims for ideal operation. Firstly, absorbing and dissipating. Secondly, to move exhaust gasses. Thirdly, to preserve the power of the engine while achieving the first two aims.

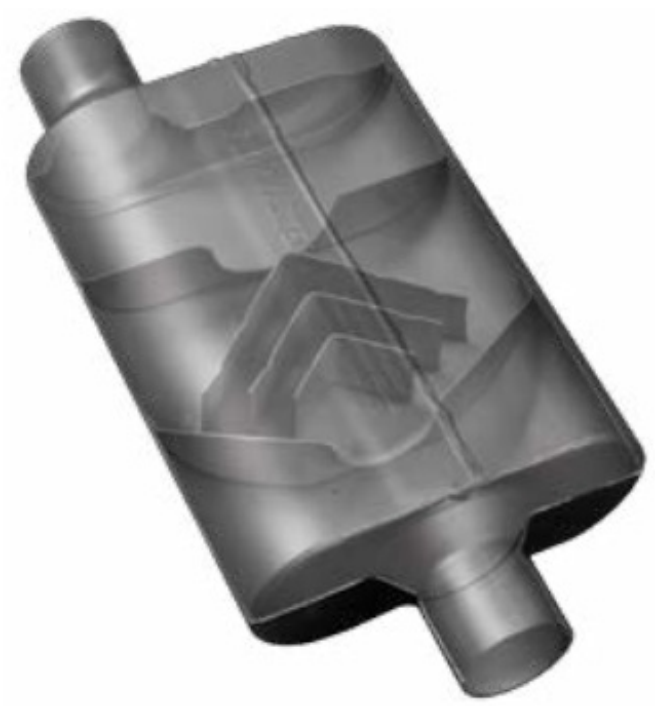

Figure 16: Design of a Muffler.

\section{Lean Combustion}

The combustion process occurring under adequately fuel-lean conditions can have desirable features, including high efficiency and low emissions. Especially essential when considering recent and fast growth regarding the cost of fossil fuels and interests over the connections between combustions and global climate changes. Lean Combustion is a remarkably real reference work on the most recent advances in lean combustion technology and systems. Lean combustion will provide specialists and engineers working on combustion apparatus and systems both the basics and the latest advancements in more efficient fuel consumption and less of unwanted emissions, while still attaining the required power output and performance. A study was once made on "The Effect of Lean Mixture Combustion and Compression Ratio in Turbocharged Gasoline Engine." Turbocharged lean combustion was performed using a multispark ignition device. The turbocharged lean operation in the A/F ratio of 21:1 achieved the same torque as the stoichiometric $\mathrm{A} / \mathrm{F}$ ratio operation is naturally powered engines. Regarding the turbocharged operation, $\mathrm{NO}$ and $\mathrm{CO}$ emissions surprisingly have reduced to about $80 \%$ and $85 \%$, respectively. 


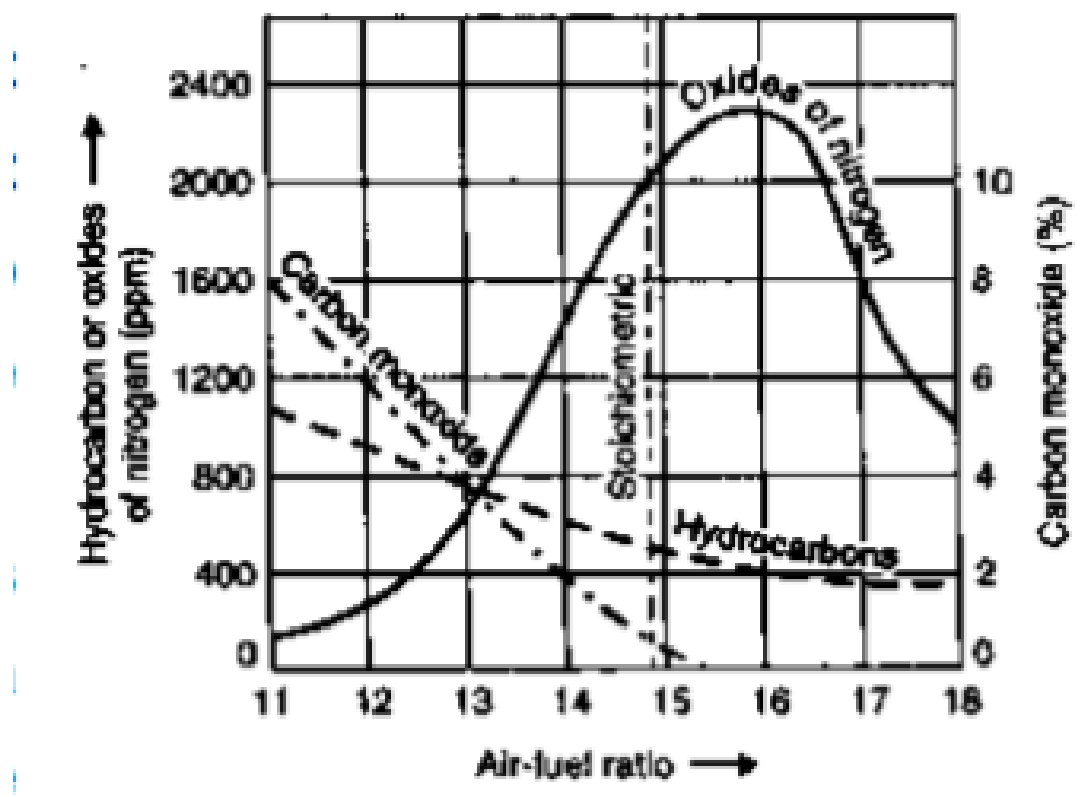

Figure 17: Pollutants vs. A/F ratio.

Figure 17: Pollutants vs. A/F ratio. Demonstrates how three major exhaust pollutant products, CO, HC, and NOx, vary from different air-fuel ratio performing on either side of the stoichiometric ratio for a very rich mixture (11:1) to very lean mixture (18:1). It can be concluded the following from the above plot/graph:

- The amount of carbon monoxide produced in the exhaust is approximately $8 \%$ for an $11: 1 \mathrm{~A} / \mathrm{F}$ ratio, but this percentage regularly decreases to 0 as the mixture is reduced to just beyond the stoichiometric ratio is on the lean side.

- Hydrocarbons produced in the exhaust gases quantify roughly 1100 parts per million (ppm) with a rich 11:1 $\mathrm{A} / \mathrm{F}$ ratio. The strength of the mixture approaches the stoichiometric ratio; its value is reduced to about 500 ppm.

- Oxides of nitrogen products produced during the combustion process are low at $100 \mathrm{ppm}$, with a rich $\mathrm{A} / \mathrm{F}$ ratio of 11:1. The strength of the mixture approaches the stoichiometric ratio, and the value rises vastly to $2000 \mathrm{ppm}$. Additional reduction of the mixture's strength to 15:1 skyrockets the value to around 2,300 ppm; weakening the mixture further at this point vastly minimizes it until, at an $18: 1 \mathrm{~A} / \mathrm{F}$ ratio, the value is 1000 ppm. 


\section{Automatic Hot Air Intake System}

The aim or function of an air intake temperature control system is to adjust, control, and maintain the temperature of the air coming into the induction system within some achievable temperature band. The system grants hot air from the exhaust manifold to be delivered directly to the carburetor in cold atmospheric conditions. Increasing the air temperature leads to decreasing the volumetric efficiency and, as a result, decreasing the engine brake power as well. However, such a system can control emissions significantly in addition to the Air injection reactor or air pump system of exhaust emission control. With the air pump, hydrocarbons and carbon monoxide in the exhaust gas are burned harmlessly in the engine exhaust manifold.

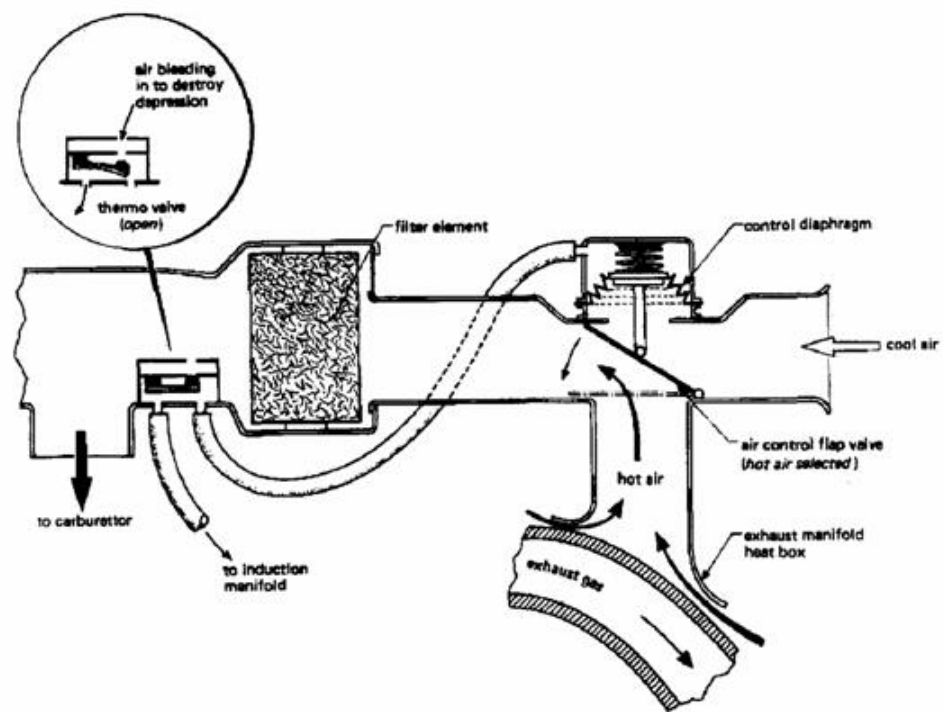

Figure 18: Automatic hot air intake system.

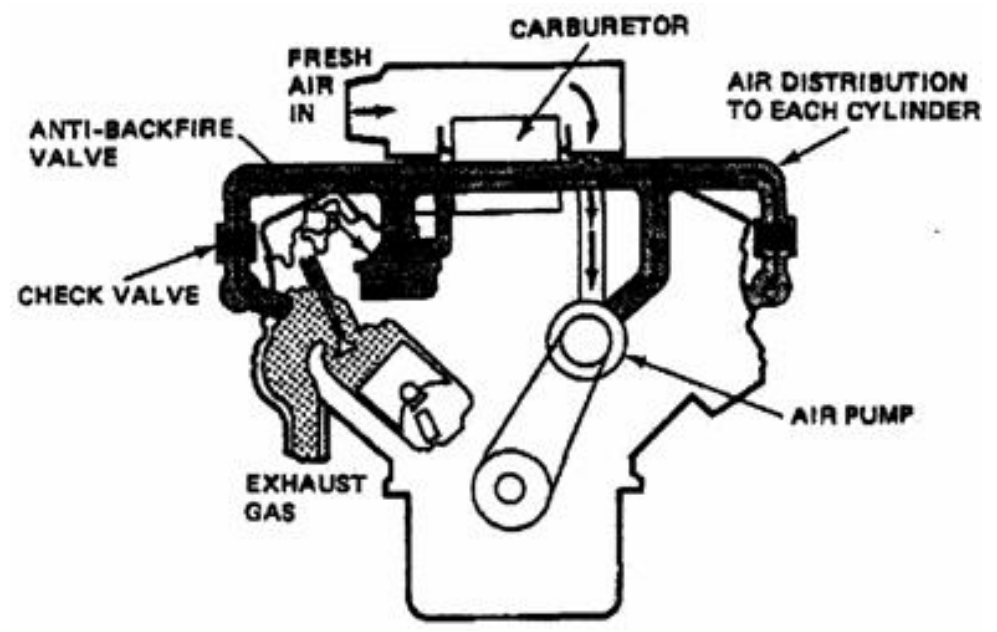

Figure 19: Air injection reactor. 


\section{Engine Compression Ratio}

The engine compression ratio is a critical engine parameter that highly affects the following:

- Surface to volume ratio of the combustion chamber.

- Engine combustion temperature.

- Thermodynamic efficiency.

- Fuel octane number for knock free engine operation.

During the 1960s, excellent and valuable high-performance car engines operated with a compression ratio of 10 to 11:1. After that, strict and tight emission standards and guidelines were legislated for the first time in 1975. As a result, the compression ratio was reduced and dropped to 8.5 to 9:1. However, high turbulence engine combustion chambers were developed in addition to using a port fuel injection system. As a result, it has been possible to increase compression ratios a bit. It has been claimed that modern gasoline engines employ compression ratios in the range of 9 to 9.5:1. A low compression ratio leads to a combustion chamber with a lower surface/volume ratio. Hence, a reduction in the volume of the quenching layer.

Furthermore, low compression ratio engines would have a lower crevice volume. These aspects or factors mentioned previously significantly reduce and minimize hydrocarbon emissions. On the other hand, lower compression ratios lead to higher exhaust temperatures, which will cause oxidation of hydrocarbons and carbon monoxide while existing in the exhaust system. Moreover, a lower compression ratio results in lower peak combustion temperatures. Therefore, the lower oxides of nitrogen (NOx) are formed. However, lowering the compression ratio's primary disadvantage is lower fuel efficiency, which leads to more $\mathrm{CO}_{2}$ emissions.

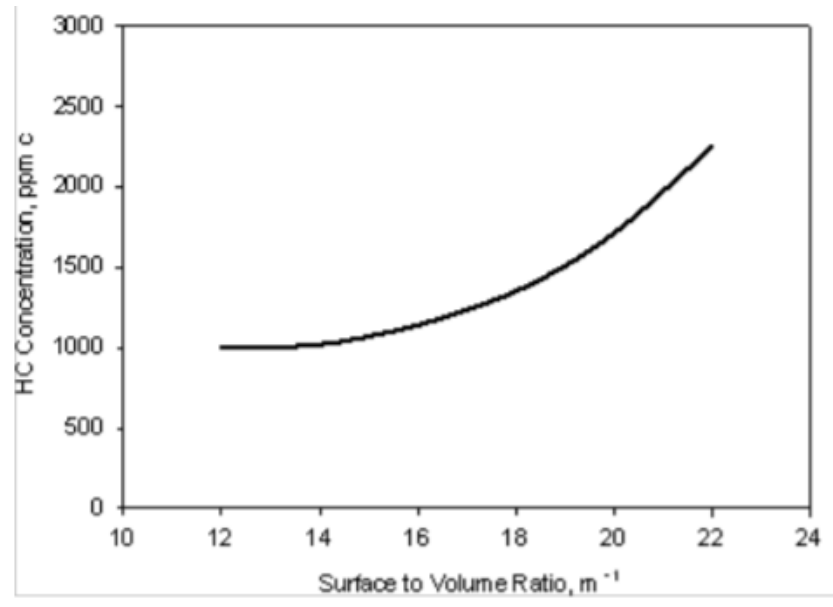

Figure 20: Effect of surface/volume ratio of the combustion chamber on hydrocarbons.

\section{Modification of Combustion Chamber}

It is commonly and conventionally nowadays to use small cylinders with hemispherical and pent roof type combustion chambers for the following reasons: 
- Engines with smaller cylinders operate at higher speeds. Hence, increasing turbulence and reducing hydrocarbon emissions.

- Smaller cylinders have less content of burned gases, which form the high-temperature adiabatic core. Therefore, as the walls are nearer to bulk gases that lead to more heat transfer from the burned gases. Such a phenomenon results in lowering the oxides of nitrogen (NOx) emissions.

- Compact hemispherical combustion chambers offer and grant the least surface: volume ratio in addition to minimum tendency to engine knocking.

When analyzing and studying the hemispherical combustion chamber, it can be claimed that it can accommodate numerous valves. However, placing two valves is more convenient due to the difficulty faced while placing four valves at the necessary valve positioning angles. A profile looking like a hemisphere is formed by combining the valve heads with the combustion chamber's surface. Higher volumetric efficiency is achieved by inclining the intake and exhaust valves, whereas increasing the valve port area. This type of combustion chamber is characterized by a low surface: volume ratio. To generate a higher air swirl rate, the intake ports are equipped with a fitting curved geometry.

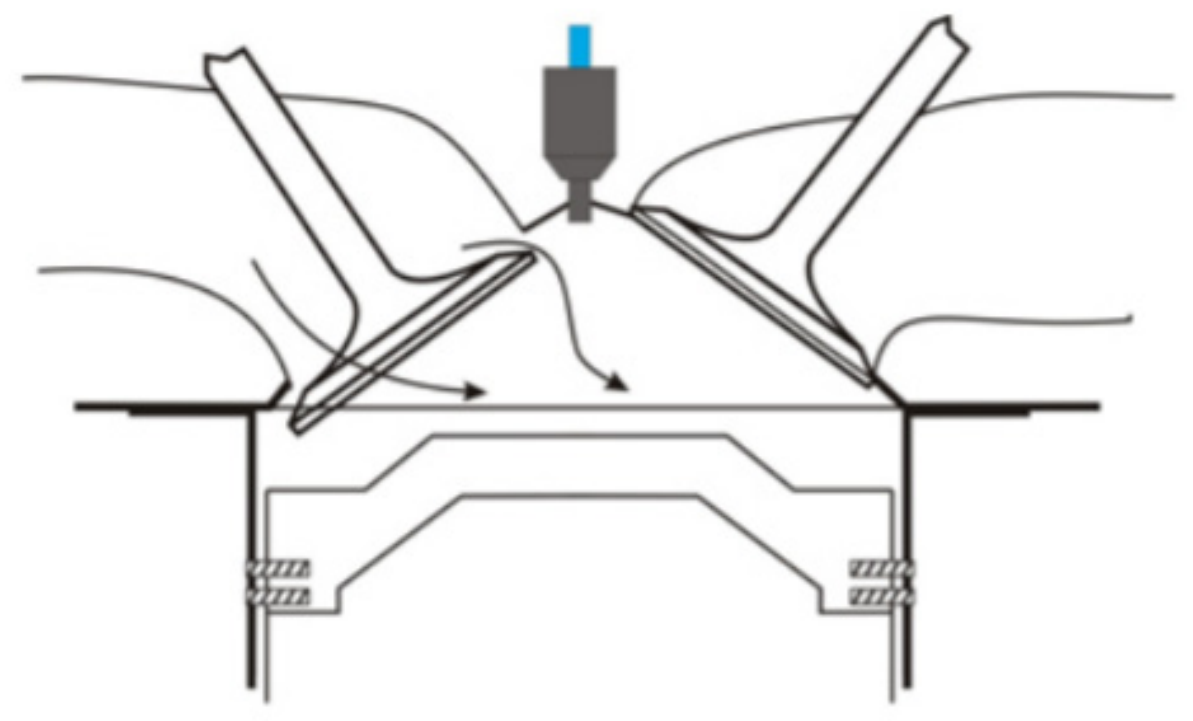

Figure 21: Hemispherical combustion chamber (generally with two valves).

Another technology was introduced regarding combustion chamber modification, which is the shallow angle pentroof combustion chamber. This type is an acceptable practical compromise, where it grants the usage of 4 valves having optimal sizes and positioning. Higher burning rates are achieved in such type of combustion chambers as it tends to have higher volumetric efficiency and tumble air motion. Moreover, this combustion chamber has lower heat transfer losses to the surroundings. Hence, quench layer thickness is reduced, which, by default, reduces hydrocarbon emissions. When compared, the pent-roof combustion chamber is shallower than the hemispherical combustion chamber. However, it has a greater surface: volume ratio, but the pent-roof combustion chamber is a satisfying combination 
between the combustion chamber's compactness and the usage of numerous valves. In practical, pent-roof combustion chambers employ 2 and 3 intake valves and 3 to 6 valves per cylinder. Commonly, 4-valve configuration is applied to combustion chambers because the inclination of the exhaust and intake valves to each other slants and tilts the valve heads to feature an arch taking the appearance of a pent roof; this is why such a name was assigned to it. Close to the center is the location of the spark plug.

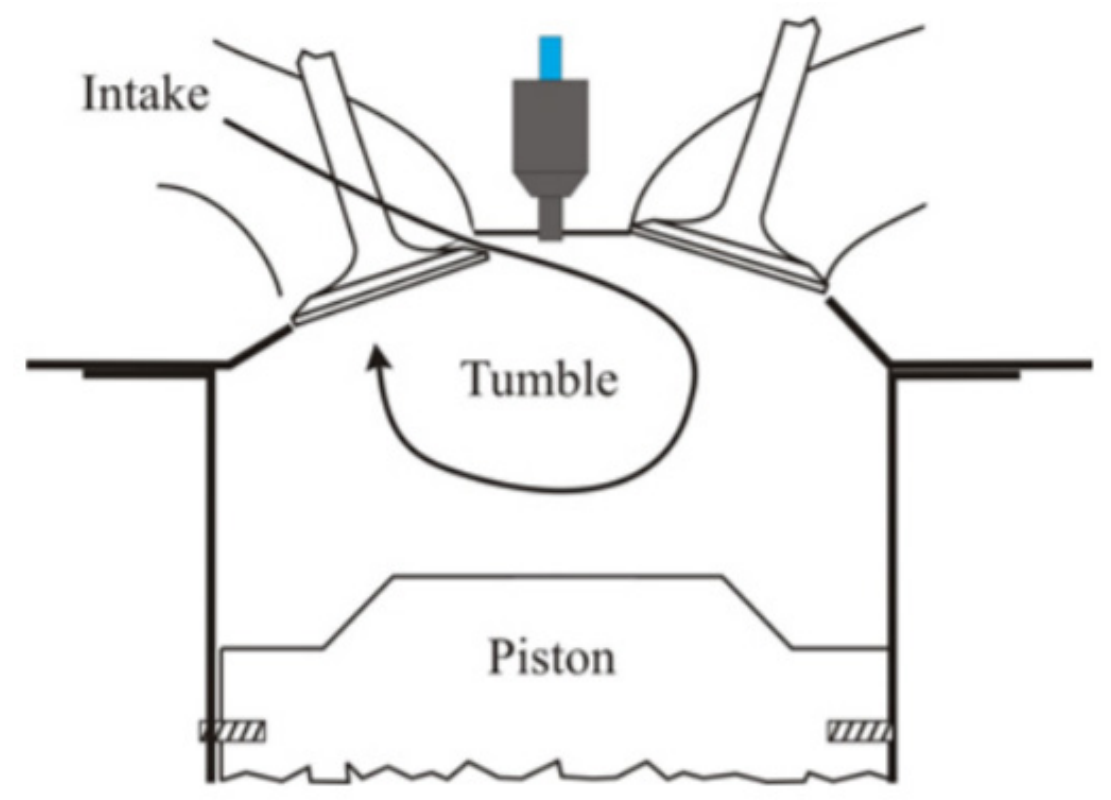

Figure 22: Pent roof combustion chamber with 4-valves for modern spark-ignition engines.

Taking into consideration, modifying combustion chambers includes avoiding flame quenching areas, where combustion might be incomplete and results in high hydrocarbon emissions. This involves reducing of surface: volume ratio and reducing space all over the piston ring.

\section{Modification of the Fuels}

The capability of a specific fuel to burn in leaner mixtures than stoichiometric ratio is an approximate sign and evidence of its potential to reduce emissions and fuel consumption as well. For example, if propane is used as a fuel instead of gasoline, this will highly lead to less carbon monoxide emissions in addition to reducing hydrocarbons and oxides of nitrogen. Furthermore, if propane is replaced with methane, carbon monoxide and hydrocarbons emissions achieve the zero level. However, only the oxides of nitrogen remain an essential factor.

Fuel System: In 1980, all gasoline spark-ignition engines engaged carburetors. At that time, a few superior exceptional models of gasoline cars engaged the electronic fuel injection (EFI) system. From 1990, the carburetor was replaced with electronically controlled multi-point port fuel injection (MPFI or PFI) in all cars produced in the united states. The port fuel injection system needs one injector per cylinder that injects fuel into each cylinder's intake port. Also, 
some engines employ an additional injector to provide extra fuel needed during starting and warm-up. Such replacement improved the volumetric efficiency, which increases power and torque. This phenomenon is that the venturi system required for the carburetor is removed, leading to less fuel vaporization in the intake manifold.

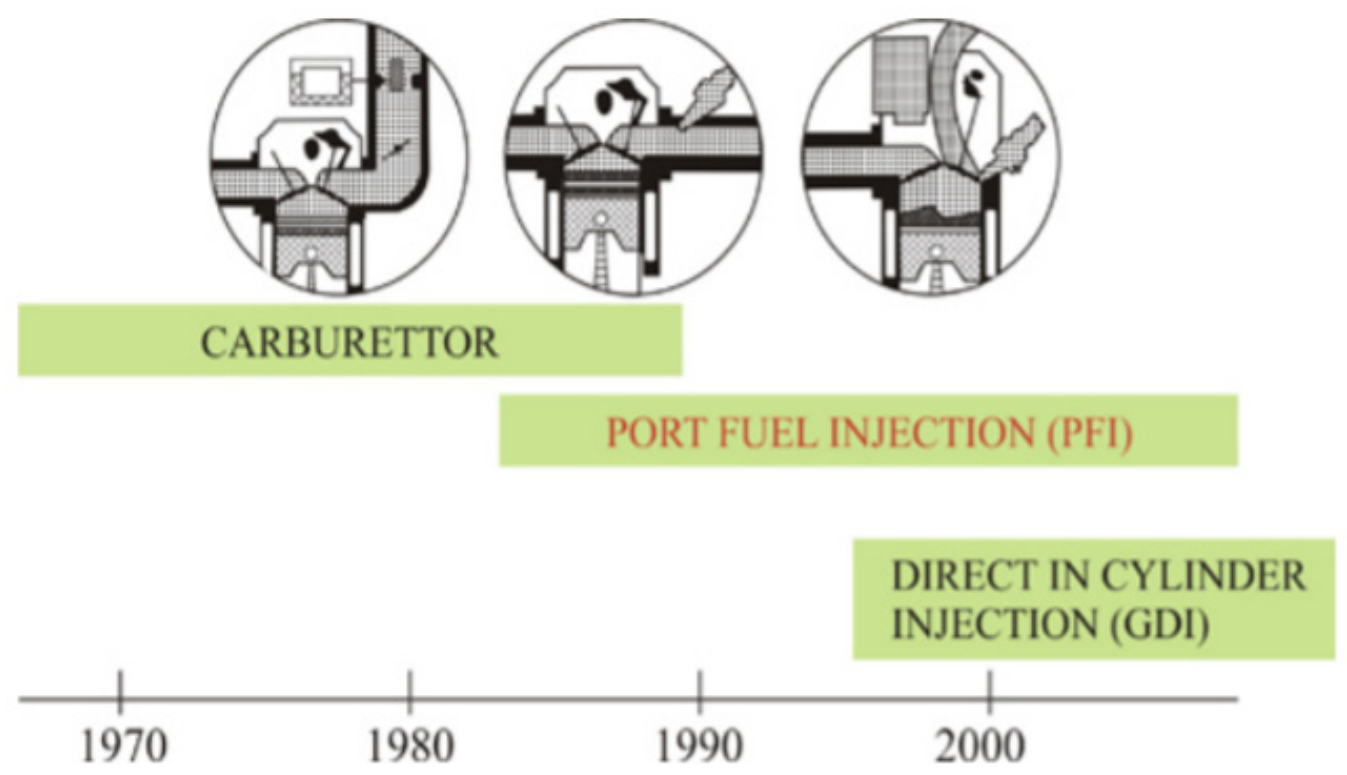

Figure 23: Trends in the development of fuel system technology for spark-ignition gasoline engines.

Considering the usage of port fuel injection alone offered a 20 to $30 \%$ reduction in hydrocarbons and a 50 to $60 \%$ reduction in carbon monoxide than the carburetor while testing over the urban driving cycle. Meanwhile, nitrogen oxides, however, increased by about $45 \%$ as for gentle smooth engine application, a leaner mixture was considered while using PFI. The closed-loop regulated and controlled stoichiometric working of the engine indicates PFI's minimum effect on the oxide of nitrogen emissions. Moreover, less carbon monoxide and hydrocarbons are acquired because more uniform fuel distribution among the engine cylinders occurs. Direct injection stratified charge (DISC) engines were introduced during the mid-1990s, where Mitsubishi and Toyota placed DISC engines on their production cars. That DISC engine works as lean as 40 to $1 \mathrm{~A} / \mathrm{F}$ ratio in addition to providing tremendous and significant reductions in engine emissions. 


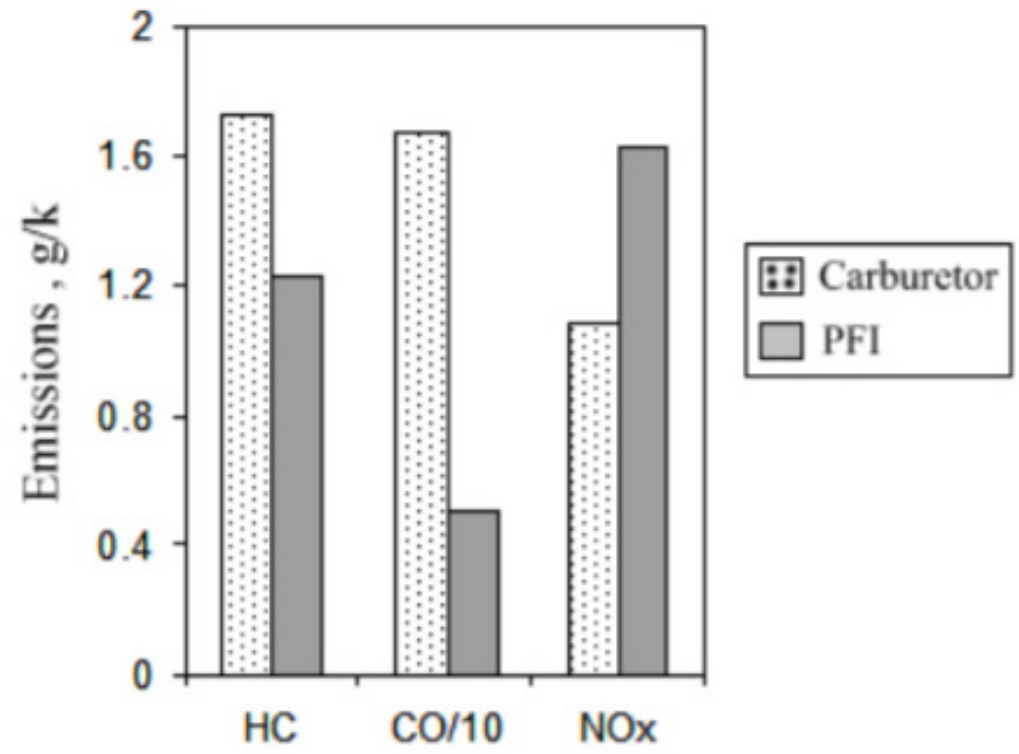

Figure 24: Comparison of engine-out emissions from carburetor and open-loop PFI engine passenger cars.

\section{Treatment of Exhaust Products of Combustion}

The emissions of the exhaust gases released from the exhaust manifold are treated to reduce overall emissions. The devices used to achieve such a task are afterburner, exhaust manifold reactor, and catalytic converters.

After Burner: It is a burner, where the air is provided and supplied to the exhaust gases, and by assisting the ignition system, the mixture is burnt. As a result, the hydrocarbon and carbon monoxide emissions formed in the combustion process due to inadequate presence of $\mathrm{O} 2$ and lack of time to burn are additionally brunt by supplying air in a separate box is well known as the afterburner.

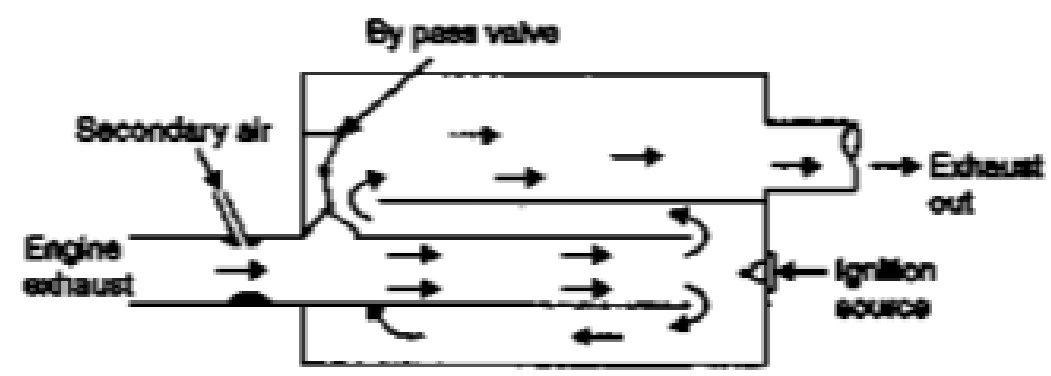

Figure 25: Direct flame afterburner. 
Exhaust Manifold Reactor: The exhaust manifold reactor is considered as a further improvement, development, and modification of the afterburner. In contrast, the design is modified to minimize heat loss and provide adequate time for mixing the exhaust and secondary air.

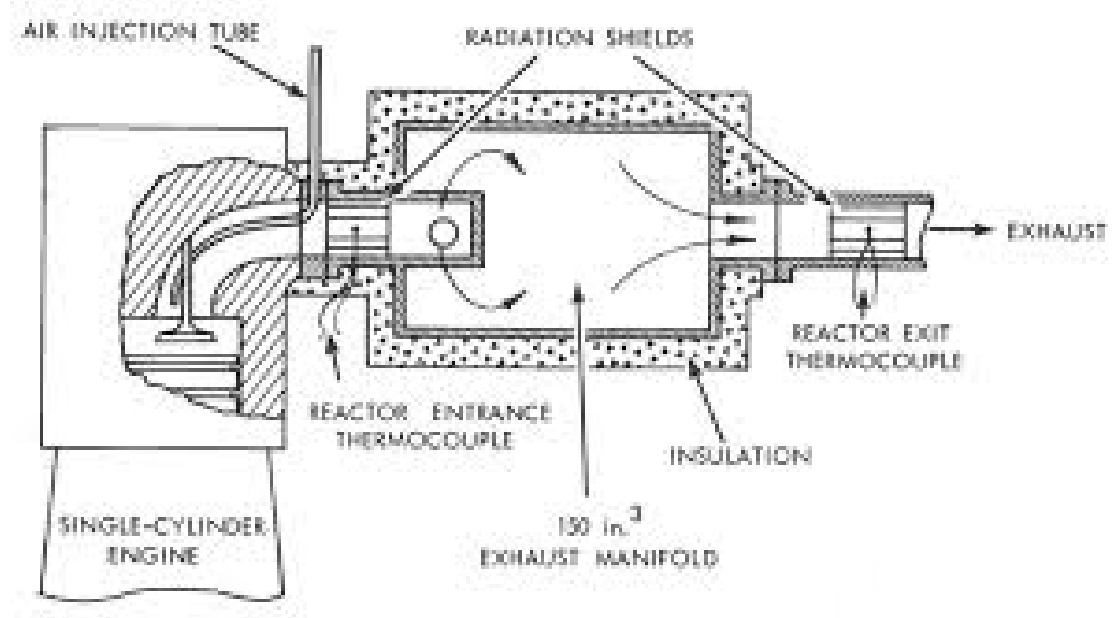

Figure 26: Exhaust manifold reactor.

Catalytic Converters: A catalytic converter is an innovative device fixed in the automobile exhaust system to minimize hydrocarbons and carbon monoxide through an oxidizing catalyst and minimize oxides of nitrogen through a reducing catalyst where that is a catalytic converter's principal function. This technology will be discussed more in-depth in the upcoming section.

\section{Catalytic Converters}

A catalytic convertor's primary function or role is to minimize hydrocarbons and carbon monoxide through an oxidizing catalyst and minimize oxides of nitrogen through a reducing catalyst while being placed in the exhaust system.

Three-way Catalytic Converter:

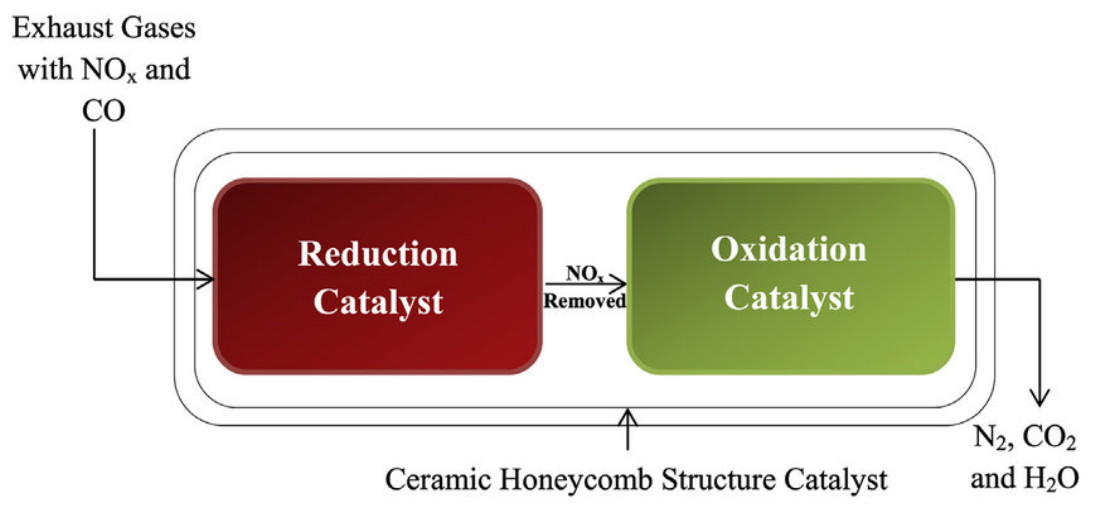


Figure 27: Block diagram of a 3-way catalytic converter.

The reduction catalyst is made of platinum and rhodium. On the other hand, the oxidation catalyst is made of platinum and palladium. Besides, the two catalysts have a ceramic honeycomb structure.

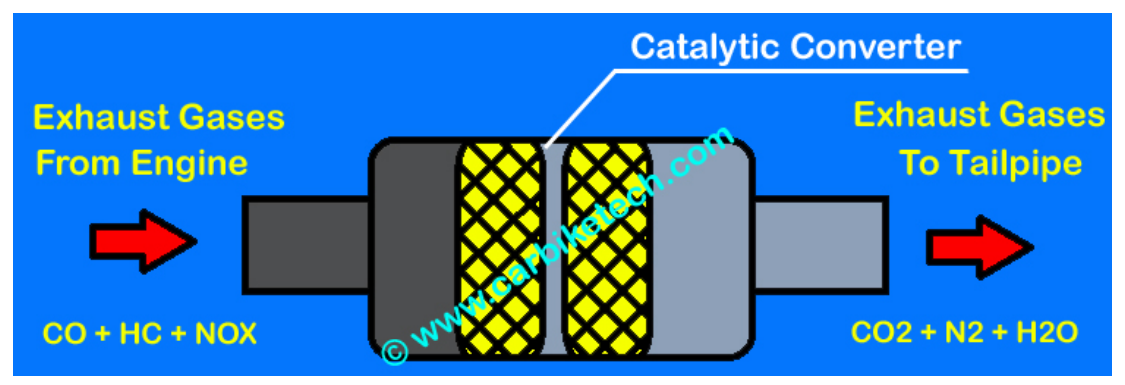

Figure 28: Three-way catalytic converter.

Stage 1 (Reduction Catalyst): Firstly, the exhaust gases pass over the reduction catalyst. It changes oxides of nitrogen (NOx) to nitrogen $\left(\mathrm{N}_{2}\right)$ and oxygen $\left(\mathrm{O}_{2}\right)$. These reactions occur when the exhaust gases pass over the reduction catalyst. $2 \mathrm{NO} \rightarrow \mathrm{N}_{2}+\mathrm{O}_{2}$

$2 \mathrm{NO}_{2} \rightarrow \mathrm{N}_{2}+2 \mathrm{O}_{2}$

Simply, the reduction catalyst takes nitrogen and oxygen from the oxides of nitrogen. As nitrogen and oxygen are non-toxic gases while oxides of nitrogen are extremely toxic and harmful.

Stage 2 (Oxidation Catalyst): On the other hand, exhaust gases that are oxides of nitrogen-free are then sent over the oxidation catalyst. The oxidation catalyst changes carbon monoxide and hydrocarbons into carbon dioxide and water. The below reactions occur when the exhaust gases pass over the oxidation catalyst.

$2 \mathrm{CO}+\mathrm{O}_{2} \rightarrow 2 \mathrm{CO}_{2}$

$\mathrm{HC}+\mathrm{O}_{2} \rightarrow \mathrm{CO}_{2}+\mathrm{H}_{2} \mathrm{O}$

Four-way Catalytic Converter: A four-way conversion system reduces emissions significantly, eliminates particulates, and follows the international emission standards and guidelines. Ceramic support coated with precious metals exists in the system, where these precious metals on ceramic decontaminate and purifies engine exhaust gases. Despite performing roughly, the same function, a four-way catalytic converter is highly advantaged over the three-way catalytic converter due to occupying less volume. 


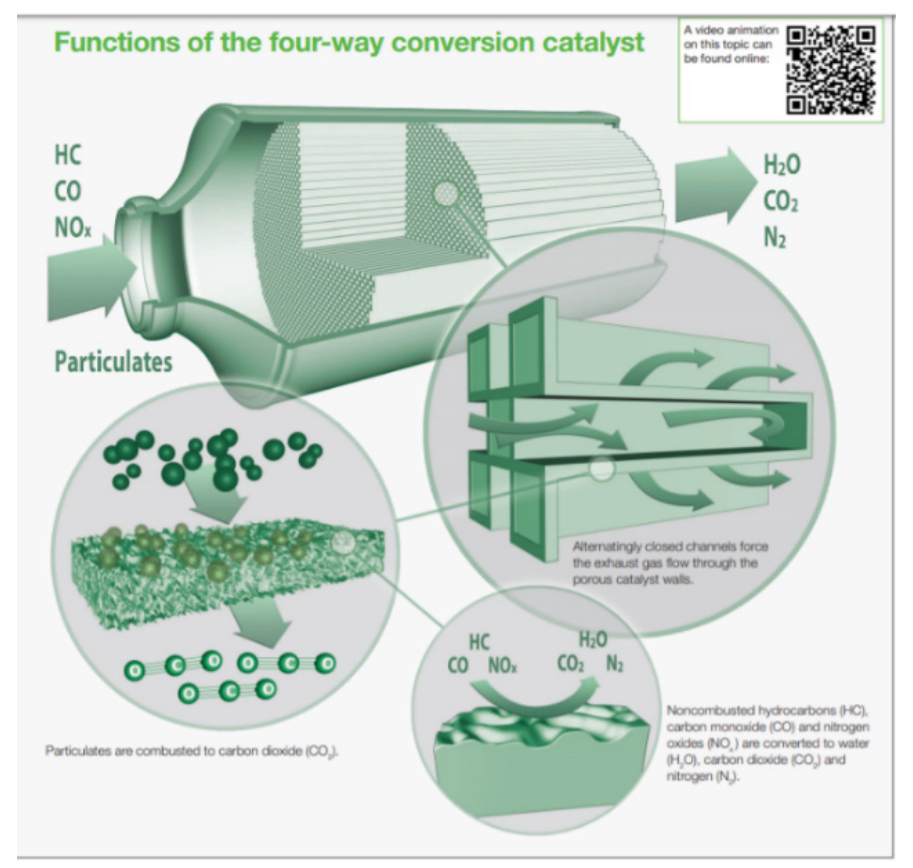

Figure 29: Four-way catalytic converter.

\section{Exhaust Gas Recirculation (EGR)}

EGR technology control is generally used to minimize oxides of nitrogen in gasoline and diesel engines. Regarding a spark-ignition engine, approximately $10 \%$ of recirculation reduces oxides of nitrogen emissions by $50 \%$. However, this leads to an imperfect combustion process, which unfortunately directly increases hydrocarbon emissions. As a result, mixture enrichment is required to reestablish combustion regularity, which leads to an additional indirect increase of hydrocarbons and carbon monoxide. The exhaust gases are recirculated to the cylinder intake charge, and this quantity is roughly about 10 to $15 \%$. Hence, reducing the quantity of $\mathrm{O}_{2}$ available for the combustion process. The exhaust gas used for recirculation is entered through an orifice and then passed through a control valve for regulating the quantity of recirculation. 


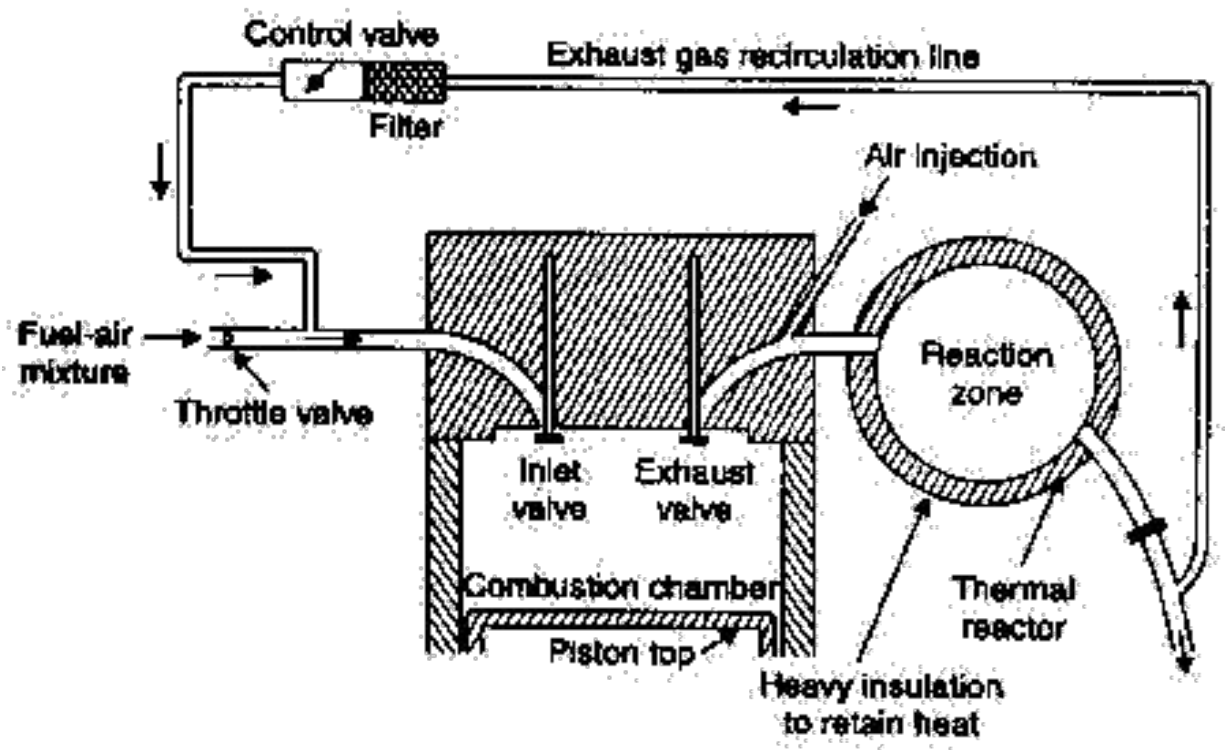

Figure 30: The arrangement of the exhaust gas recirculation (EGR) system.

It can be concluded and visualized that nitrogen's maximum emission oxides occur during lean mixture limits while gas recirculation is minimum significant. Regarding hydrocarbon (HC) and carbon monoxide (CO) emissions, the lean mixture is favored. It has been claimed that $15 \%$ of recycling reduces oxides of nitrogen by $80 \%$. However, on the other hand, it increases hydrocarbon and carbon monoxide emissions by 50 to $80 \%$. These are two clashing needs of this emission control system. Therefore, a solution for such a clash is maintaining a package system that has both oxides of nitrogen and hydrocarbon/carbon monoxide control devices.
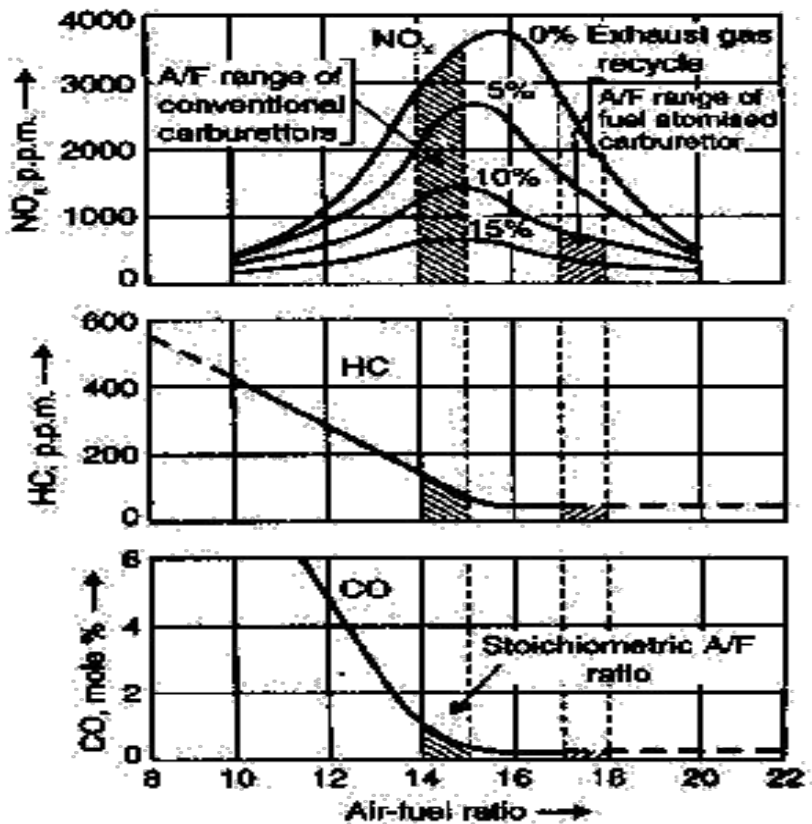

Figure 31: Effect of recycling of gas on oxides of nitrogen concentration. 


\section{Total Emissions Control Packages}

It is well known and claimed that any control technology used to reduce nitrogen oxides, unfortunately, increases hydrocarbons and carbon monoxide emissions and vice-versa. Therefore, it is of principal concern and priority to develop a control technology that could reduce oxides of nitrogen, hydrocarbons, and carbon monoxide emissions to a wanted level at the same time. The following two packages have been developed and introduced to attain and reach the required results overcoming the conflict:

1. Thermal reactor package

2. Catalytic converter package.

Such a method and control technology adopts three basic techniques of emission control:

1. Thermal reactors depend on homogeneous oxidation to control carbon monoxide and hydrocarbons.

2. Oxidation catalyst for carbon monoxide and hydrocarbons.

3. Double catalyst system, where a reduction catalyst for oxides of nitrogen and oxidation catalyst for carbon monoxide and hydrocarbons are linked and connected in series.

Thermal Reactor Package: A thermal reactor is considered a chamber designed to offer enough time for allowing the oxidation of carbon monoxide and hydrocarbons to occur. To improve converting $\mathrm{CO}$ to $\mathrm{CO}_{2}$, the spark is choked off to increase the exhaust temperature. An actual thermal reactor, commonly made of high nickel steel used in vehicles, adopts two big exhaust manifolds to allow more significant time for burning hydrocarbons and carbon monoxide with oxygen. A subordinate pump introduces and supplies fresh air into the reactor regarding keeping a flame consistently burning, where such a procedure reduces hydrocarbons and carbon monoxide. Roughly $10-75 \%$ of the gas is re-circulated after cooling in the intercooler to minimize the evolution of nitrogen oxides. The thermal reactor package reduces emissions of oxides of nitrogen, hydrocarbons, and carbon monoxide to the desired level. However, that compromises $20 \%$ less power in addition to $10 \%$ more fuel consumption.

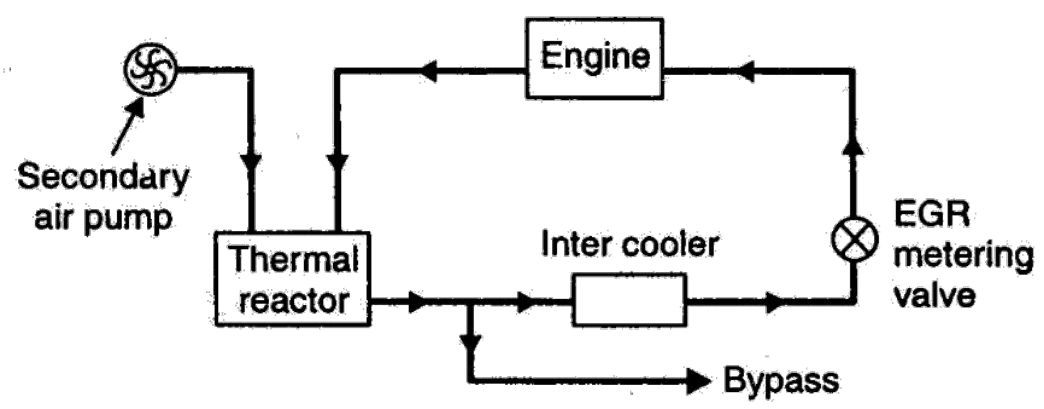

Figure 32: Thermal reactor package. 
Catalytic Converter Package: The operating standard or fundamental of the catalytic converter package is to control numerous air pollutants' emission levels. This is achieved by varying the chemical characteristics of the exhaust gases. Compared to the thermal reactor package, this package needs non-leaded fuel, where lead weakens and scales down the catalytic action. Moreover, when compared to the thermal one, the main pro of this converter is that it grants a partial decoupling of emission control from engine operation. The nitrogen catalyst oxides are the first component in the exhaust flow path, and it does not allow heat transfer. Proceeding by is the next component: the hydrocarbons/carbon monoxide catalyst, which dissipates and discharges much heat that may cause the burning of the component itself. However, such an obstacle is solved by introducing and injecting air by a secondary air pump. To increase the converter's life, a bypass valve is used. Also, exhausts are circulated through an intercooler for achieving better control of oxides of nitrogen. In a catalytic converter package, the loss of power is approximately $30 \%$, and the fuel consumption is approximately $10 \%$ more than usual.

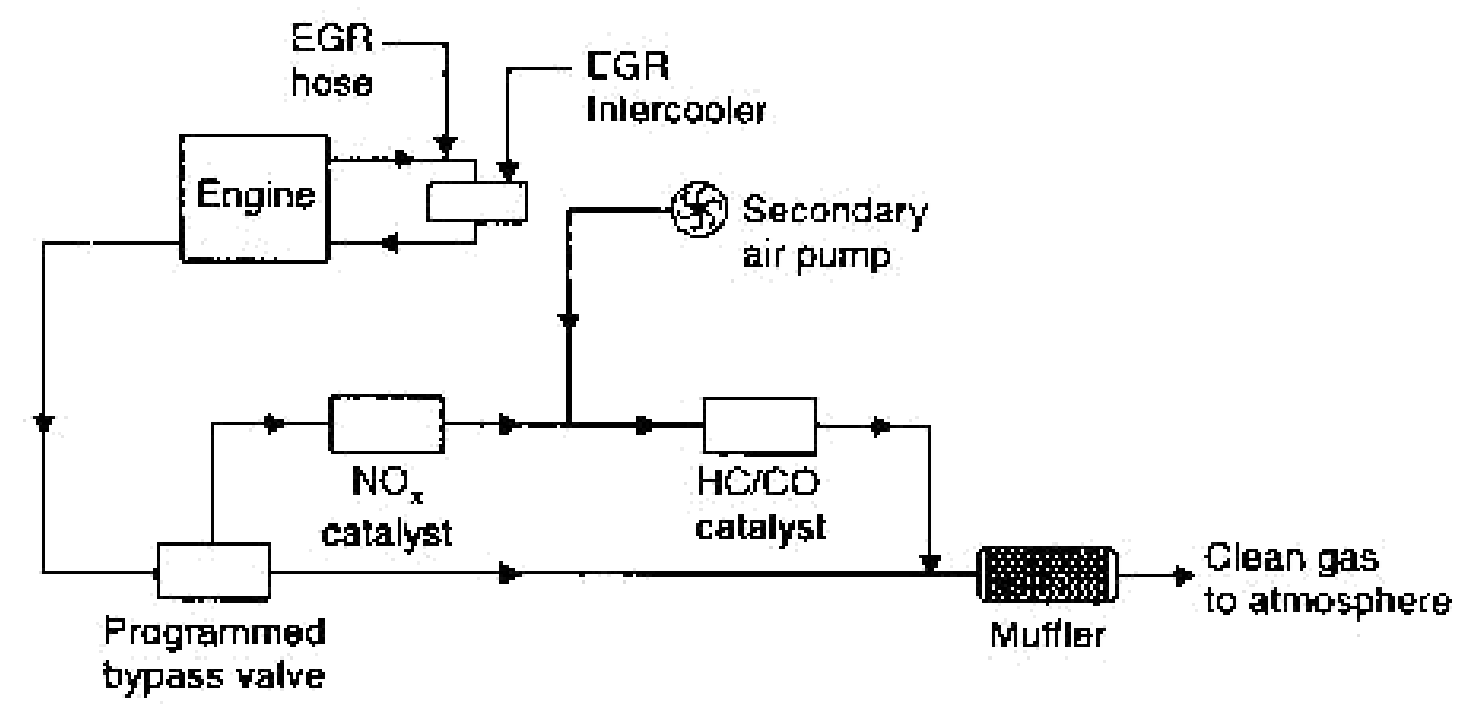

Figure 33: Catalytic converter package.

Comparison: Table 1: Comparison between the catalytic converter package and the thermal reactor package.

\begin{tabular}{|c|c|c|}
\hline Oxidizing Systems & Catalytic Converter & Thermal Reactor \\
\hline \multicolumn{3}{|c|}{ Advantages } \\
\hline Reduction of HC and CO & $\mathbf{8 0 - 9 0 \%}$ & $\mathbf{8 0 - 9 0 \%}$ \\
\hline Reduction of NO & No & No \\
\hline Reduction of Aldehydes & $\mathbf{5 0 \%}$ or more & $\mathbf{5 0 \%}$ or more \\
\hline
\end{tabular}




\begin{tabular}{|c|c|c|}
\hline $\begin{array}{c}\text { Use the same design for all } \\
\text { vehicles }\end{array}$ & possible & possible \\
\hline Life & Up to $80000 \mathrm{~km}$ & Up to $165000 \mathrm{~km}$ \\
\hline \multicolumn{3}{|c|}{ Disadvantages } \\
\hline Cost & High & High \\
\hline Volume & High & Higher \\
\hline Engine Mounting required & No & Yes \\
\hline Weight added & Some & Significant \\
\hline Container durability Problem & Yes & Yes \\
\hline $\begin{array}{c}\text { Raises engine compartment } \\
\text { temperature }\end{array}$ & Depends on location & Yes \\
\hline Requires Non-leaded fuel & Probably & No \\
\hline Requires air injection & Some do & Some do \\
\hline Lowers fuel economy & No & Probably yes \\
\hline Decreases power & Depends on back pressure & Depends on back pressure \\
\hline $\begin{array}{c}\text { Loss of catalytic material due } \\
\text { to attrition }\end{array}$ & Yes & No \\
\hline May emit other toxic material & Yes & No \\
\hline
\end{tabular}

\section{Pre-combustion Control; (Positive Crankcase Ventilation (PCV).}

Positive Crankcase Ventilation is a system that was introduced to abolish and eliminate toxic gases from the engine and avoid their discharge into the air and surroundings. The PCV system accomplishes its primary function by employing a manifold vacuum to draw gases from the crankcase into the intake manifold. The gases are directed accompanied by the air and fuel mixture to the combustion chambers to get burned. The flow is regulated and controlled by the PCV Valve, which is considered the most critical component in the PCV. The principle and the main function of 
the PCV valve are metering the gases' flow from the crankcase to the intake manifold, which is essential to offer and grant suitable ventilation for the crankcase without disturbing the air and fuel mixture for the combustion process.
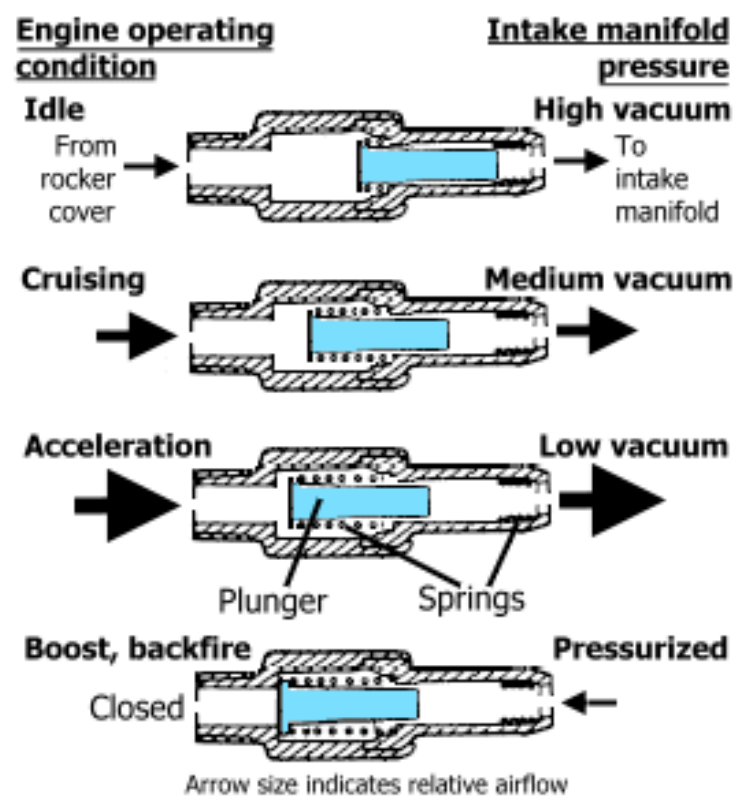

Figure 34: PCV Valve design and operation.
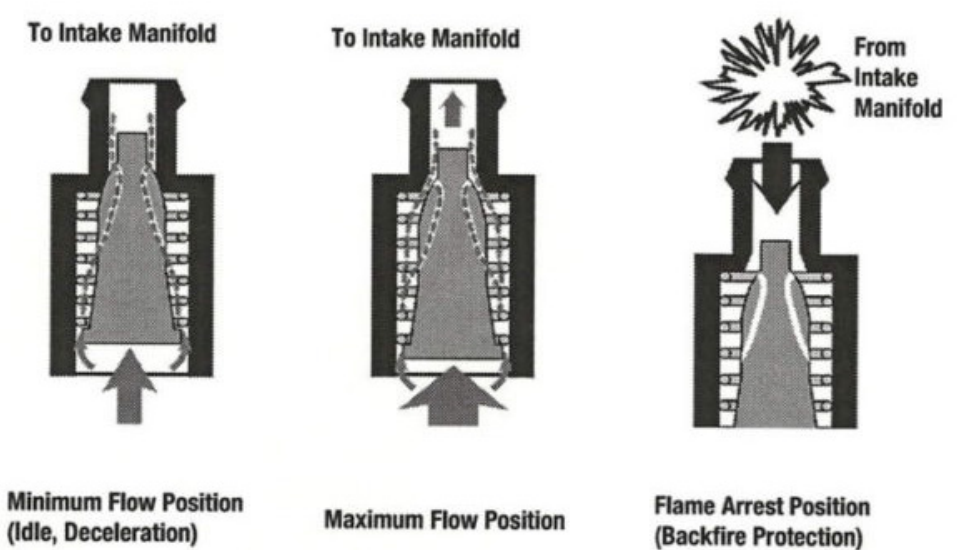
(Idle, Deceleration)

Maximum Flow Position

Flame Arrest Position (Backfire Protection)

Figure 35: Typical PCV valve operation.

Open PCV Systems: An open PCV system draws the fresh air through an oil filler cap outlet. Such a procedure encounters no problems as long as the gas' volume is minimum. Meanwhile, when the crankcase gases become extra, it is directed back through the oil filler cap outlet and into the open air and surroundings. Although the open PCV system successfully eliminates toxic gases from the crankcase, it is not considered an efficient emissions control technology. 
Closed PCV Systems: A closed PCV system draws the fresh air from the air filter housing. In such a system, the oil filler cap is not an outlet. Therefore, extra gases will be forced and directed back to the air filter housing and then into the intake manifold. However, this system does not permit and blocks regular or extra gases from being emitted to the air and surroundings. The closed PCV system is considered efficient and practical emissions control technology.

\section{Valve Gear Design}

Multiple Valves: It is common in an SI engine to use four valves per cylinder, where two valves are for intake, and two valves are for exhausts. Using multiple valves has the following advantages:

1. When compared to two valves configuration, it increases the valve flow area.

2. The spark plug can be fixed at the center. Hence, reducing the flame travel distance leading to faster and less knocking propensity combustion.

3. Just one intake valve can be used at low velocities and low loads to achieve high intake mixture velocity leading to high turbulence, enhancing combustion at lighter loads. Meanwhile, at high velocities and high loads, the two valves open.

4. Achieving higher volumetric efficiency as the two intake valves may be arranged with different valve timings and lifts.

Variable Valve Timings and Lift: Continuously variable camshaft phasing over the engine's whole power range is achieved by variable valve timing control. Several manufacturers have made their designs of variable valve actuation. Variable valve timing can reduce the emissions of oxides of nitrogen by 30 to $70 \%$. A small alteration in the hydrocarbon emissions between the fixed and variable valve timings occur. However, the carbon monoxide emissions are a function of the $\mathrm{A} / \mathrm{F}$ ratio. To take advantage of the ram effect, higher volumetric efficiency is needed at high velocities. Therefore, large valve overlap is required. An increase in the valve overlap leads to an increase in a leftover gas fraction at low velocities. As a result, oxides of nitrogen emissions are reduced. However, hydrocarbon emissions are increased. 


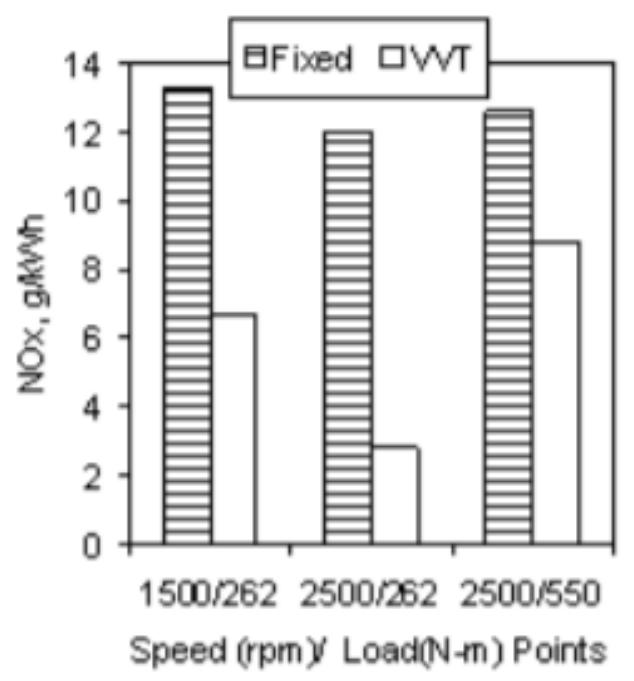

Figure 36: Typical oxides of nitrogen emissions with fixed and variable valve timings.

\section{Conclusions}

In conclusion, to sum things up, the emissions' issue will always remain a controversial topic. People cannot stop using automobiles or vehicles, specifically the globally widespread ones operated by spark-ignition engines; many businesses and daily-basis activities mainly depend on transportation. It can be claimed that the issue is complicated through various and even numerous aspects. Humankind, animals, and plants are negatively influenced and affected by these emissions. Moreover, the environmental context will always be a concern, especially when technology witnessed still witnessing an era and massively significant progress through many aspects. Hopefully, specialists in controlling emissions technologies will always improve, develop, and enhance the controlling technologies and methods. Compared with the past decades, it can be quickly concluded that automotive engineers and researchers follow an improvement trend. Many innovations have been brought to the table. Effective and efficient solutions are focused on and can be concluded from the great developments that occurred by time. Another alternative for offering more comprehensive solutions in such a field originated and appeared later, which is mainly considering changing the powertrain. Hybridized vehicles have been introduced, which are mainly operating on electricity leading to zero emissions. They are significantly cleaner and can be considered a better alternative for many. However, they compromise other factors such as power, for example, which is inconvenient for many. When it comes to summarizing the emission control technologies in spark-ignition engines, it can be claimed that the main and major technologies among numerous methods are shortlisted in these factors. Each technology has its branches and subcategories.

- Modifications in the engine design and operating parameters.

- Treatment of exhaust products of combustion.

- Modification of the fuels. 
In this report, mainly the most prominent and effective technologies were discussed. The points covered were related but not limited to the three main categories mentioned above.

\section{Recommendation for Future Research:}

The following procedures are recommended for future research and investigations, as they may have the potential for better controlling of emissions in a spark-ignition engine:

- Consider recruiting $100 \%$ alcohol to the engine accompanied by varying the spark ignition timing.

- Studying and analyzing the effect of the A/F ratio on the emissions and performance factors when varying the throttle openings.

- Revival and recovery of lean-burn petrol direct injection systems and introducing the oxides of nitrogen trap technology to the system. Such a procedure may influence emissions and fuel economy.

- Work on improving and enhancing the thermal durability of catalytic converters.

\section{Bibliography}

Association, M. \&. (2020, April 20). Positive Crankcase Ventilation (PCV). Retrieved from HASTINGS

PREMIUM FILTERS: http://www.hastingsfilter.com/Literature/TSB/94-2R1.pdf

Branislav Sarkana, O. S. (2017, April). Investigation of Exhaust Emissions of Vehicles with the Spark Ignition Engine within Emission Control. Retrieved from ScienceDirect:

https://www.sciencedirect.com/science/article/pii/S1877705817319677

Dhamangaonkar, V. S. (2014, January). Design Principles for an Automotive Muffler. Retrieved from Researchgate: researchgate.net/publication/296778473_Design_principles_for_an_automotive_muffler

Dunn-Rankin, D. (2008). Lean Combustion Technology and Control. California: Academic Press.

EMISSION CONTROL FOR SI ENGINES/VEHICLES. (2019, April 20). Retrieved from NPTEL:

https://nptel.ac.in/content/storage2/courses/112104033/pdf_lecture/lecture19.pdf

Emission Control for Spark-Ignition Engines. (n.d.). Retrieved from TheCarTech:

http://www.thecartech.com/subjects/engine/Emission_Control.htm

Neil R. Collins, a. M. (2007, January). Three-way Catalyst Emissions Control Technologies for Spark-ignition Engines - Recent Trends and Future Developments. Retrieved from Researchgate:

https://www.researchgate.net/publication/225811594_Three- 
way_catalyst_emissions_control_technologies_for_spark-ignition_engines_-

_Recent_trends_and_future_developments

Priyadarsini, I. (2013, March). Control of Exhaust Emissions from Spark Ignition Engine. Retrieved from Researchgate:

researchgate.net/publication/274958612_Control_of_Exhaust_Emissions_from_Spark_Ignition_Engine

Sher, E. (1998). Handbook of Air Pollution from Internal Combustion Engines. Academic Press.

Songyol Lee, J. T. (1991, November 1). The Effect of Lean Mixture Combustion and Compression Ratio in Turbocharged Gasoline Engine. Retrieved from SAE INTERNATIONAL:

https://www.sae.org/publications/technical-papers/content/912477/

T, J. (2020, April 21). Retrieved from

http://www.nitc.ac.in/dept/me/jagadeesha/Internal_Combustion_Engines/Chapter5.pdf

ViannaI, J. N., ReisI, A. d., OliveiraI, A. B., FragaII, A. G., \& SousaIII, M. T. (2005, September). Reduction of pollutants emissions on SI engines - accomplishments with efficiency increase. Retrieved from Scielo:

http://www.scielo.br/scielo.php?script=sci_arttext\&pid=S1678-58782005000300002\&lng=en\&nrm=iso\&tlng=en

W. Addy Majewski, H. J. (2019, March). Engine Emission Control. Retrieved from DieselNet:

dieselnet.com/tech/engine_emission-control.php\#methods 